\title{
Cancer stem cells from a rare form of glioblastoma multiforme involving the neurogenic ventricular wall
}

Shengwen Calvin $\mathrm{Li}^{1,4,5^{*}}$, Long $\mathrm{TV} \mathrm{U}^{1,5}$, Hector W Ho ${ }^{2,3}$, Hong Zhen Yin ${ }^{4}$, Vic Keschrumrus ${ }^{1}$, Qiang Lu ${ }^{7}$ Jun Wang ${ }^{7}$, Heying Zhang ${ }^{7}$, Zhiwei Ma ${ }^{6}$, Alexander Stover ${ }^{8}$, John H Weiss ${ }^{4}$, Philip H Schwartz ${ }^{8,9}$ and William G Loudon ${ }^{1,2,3}$

\begin{abstract}
Background: The cancer stem cell (CSC) hypothesis posits that deregulated neural stem cells (NSCS) form the basis of brain tumors such as glioblastoma multiforme (GBM). GBM, however, usually forms in the cerebral white matter while normal NSCs reside in subventricular and hippocampal regions. We attempted to characterize CSCs from a rare form of glioblastoma multiforme involving the neurogenic ventricular wall.

Methods: We described isolating CSCs from a GBM involving the lateral ventricles and characterized these cells with in vitro molecular biomarker profiling, cellular behavior, ex vivo and in vivo techniques.

Results: The patient's MRI revealed a heterogeneous mass with associated edema, involving the left subventricular zone. Histological examination of the tumor established it as being a high-grade glial neoplasm, characterized by polygonal and fusiform cells with marked nuclear atypia, amphophilic cytoplasm, prominent nucleoli, frequent mitotic figures, irregular zones of necrosis and vascular hyperplasia. Recurrence of the tumor occurred shortly after the surgical resection. CD133-positive cells, isolated from the tumor, expressed stem cell markers including nestin, CD133, Ki67, Sox2, EFNB1, EFNB2, EFNB33, Cav-1, Musashi, Nucleostemin, Notch 2, Notch 4, and Pax6. Biomarkers expressed in differentiated cells included Cathepsin L, Cathepsin B, Mucin18, Mucin24, c-Myc, NSE, and TIMP1. Expression of unique cancer-related transcripts in these CD133-positive cells, such as caveolin-1 and -2, do not appear to have been previously reported in the literature. Ex vivo organotypic brain slice co-culture showed that the CD133+ cells behaved like tumor cells. The CD133-positive cells also induced tumor formation when they were stereotactically transplanted into the brains of the immune-deficient NOD/SCID mice.
\end{abstract}

Conclusions: This brain tumor involving the neurogenic lateral ventricular wall was comprised of tumor-forming, CD133-positive cancer stem cells, which are likely the driving force for the rapid recurrence of the tumor in the patient.

Keywords: Glioblastoma multiforme, Primary tumors, Brain tumor stem cells, Cancer stem cells, Organotypic brain slice culture

\footnotetext{
* Correspondence: shengwel@uci.edu

${ }^{1}$ Neuro-Oncology Research Laboratory, Center for Neuroscience and Stem

Cell Research, Children's Hospital of Orange County (CHOC) Research

Institute, 455 South Main Street, Orange, CA 92868, USA

${ }^{4}$ Department of Neurology, University of California Irvine, Orange, CA 92862,

USA

Full list of author information is available at the end of the article
} 


\section{Background}

Despite aggressive surgery, radiation therapy, and advances in chemotherapy, malignant brain and spinal cord tumors remain a leading cause of morbidity and mortality for children and adults $[1,2]$. There are few effective treatment options for brain cancer patients, especially for those with diffuse malignant gliomas. The prognosis for malignant brain tumors remains dismal, the long-term survival statistics being very poor. There is also a growing body of data which identify permanent disability among the "fortunate" survivors $[3,4]$. A fundamentally new research direction to develop new approaches to treat brain tumors is desperately needed.

Cancer stem cells (CSCs) have been defined as immortal cells within a tumor that are capable of unlimited self-renewal and which drive tumor genesis $[5,6]$. This new insight into the nature of cancer has resulted from the isolation and preliminary characterization of CSCs from many malignancies, including leukemia, multiple myeloma, squamous cell cancer, malignant melanoma, breast cancer, and brain tumors, such as medulloblastoma, ependymoma and malignant glioma [7,8]. Although questioned because of inconsistent biomarker expression [9] and the different purification methods employed [10-12], the CSC model has important implications for cancer therapy.

Normal neural stem cells (NSCs) that have been engineered for tumoricidal activity have been proposed as a novel therapy for malignant brain tumors because they can seek out the tumor cells [13-15]. This is particularly important because diffused glial tumors, brain stem tumors and metastatic tumors may be surgically inaccessible due to tumor growth dispersed throughout eloquent tissues. However, the clinical benefits versus possible detrimental effects have not yet fully been determined. Indeed, normal NSCs reside in the subventricular zone; previous reports have suggested that the tumors involving the subventricular zone of the lateral ventricle might originate from neural stem cells located in the subventricular zone [16-23]. It is well established that the tumor microenvironment plays a critical role for tumor progression. Although they may migrate into the subventricular zone, and hijack and recruit normal NSCs to facilitate tumor progression, malignant gliomas such as glioblastoma multiforme (GBM) usually form in the cerebral white matter.

We have shown that normal stem cells and cancer cells share p53 signaling pathways [24], implying the convergence of stem cells and cancer for signaling pathways [25]. These results prompted us to hypothesize that the convergence of stem cells and cancer may drive tumor recurrence by subclonal switchboard signal activation [26]. Previous reports have presented either a clinical description or molecular and cellular characterization of brain tumors, providing an incomplete story. Here, we describe, in detail, an aggressive GBM that involved the subventricular zone in which normal stem cells reside in. The clinical characterization includes the patient's clinical history, diagnosis, brain imaging studies, invasive surgery, and pathology. The molecular characterization of the resulting brain tumor stem cells includes in vitro, ex vivo and in vivo analyses. Taken together, our emphasis on research relevant to brain cancer patients covers an approach from clinical presentation to relevant laboratory research, which may narrow considerably a gap that exists between clinicians and basic research scientists. We have provided a comprehensive review of the cancer stem cell field, which may help design future therapies against brain tumors.

\section{Results}

As shown in Figure 1, the recurrent tumor showed higher CD133 expression than the primary tumor from the same young patient on both tumor tissue and cultured cell levels (Figure 1d). The result prompted us to hypothesize that the tumor residual CD133 positive cells may drive the tumor to recur. To address this hypothesis, we obtained a second tumor specimen from another patient to sort for CD133+ cells and followed up with comprehensive characterization, including imaging, surgical, pathological, molecular, cellular, and biological features.

\section{Imaging of the tumor before surgery}

A computed tomography (CT) scan identified an area of heterogeneous soft tissue density in the left parietal lobe. There was a small ill-defined area of increased density in this region, which might represent hemorrhage. There was marked surrounding vasogenic edema and mass effect on the adjacent left lateral ventricle.

MRI of the brain, with contrast, showed a large heterogeneously ring-like enhancement within the left occipitoparietal lobe, measuring $6.0 \times 4.5 \mathrm{~cm}$ and associated with marked edema (Figure 1e). There was a mild midline shift to the right by $\sim 5.0 \mathrm{~mm}$. There were also severe periventricular changes with increased signal. MRI images, obtained with gadolinium-enhancement, showed an early subacute stage of intracranial hemorrhage. There was left parietal hemorrhage measuring on the order of $3.7 \times 3.3 \times 2.1 \mathrm{~cm}$, associated with vasogenic edema. These findings were consistent with those in the CT scan.

\section{Surgical therapy effectively debulked the tumor mass}

A linear incision was made in the left parietooccipital region. Following craniotomy and dual incision, a plane was developed between the tumor and the cortical white matter, and circumferentially dissecting along the plane took place. Intraoperative specimens were sent for frozen section examination, confirming the diagnosis of 

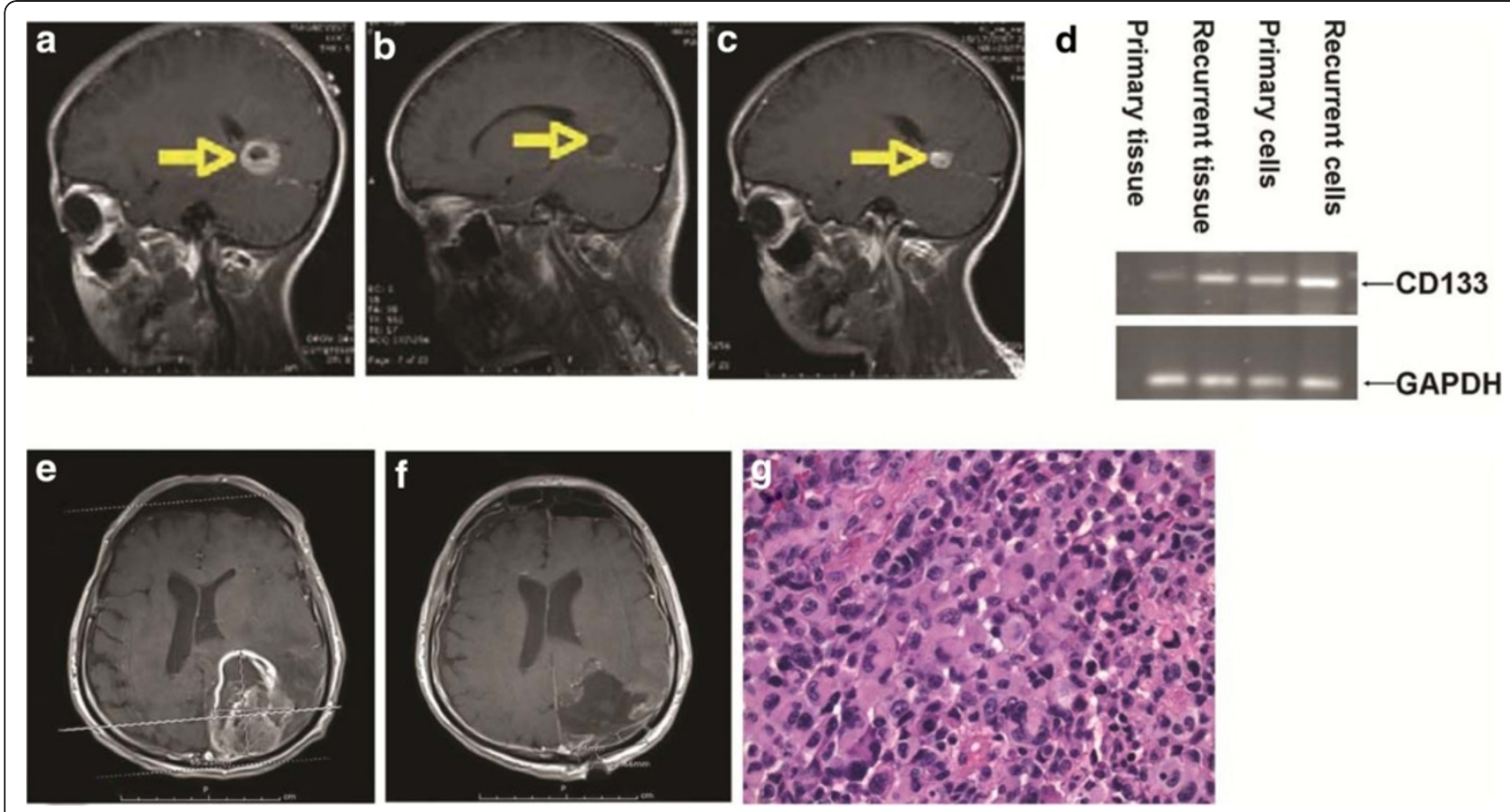

Figure 1 Clinicopathological presentation of the brain tumor. The child patient: MRI images show that primary tumor diagnostics, resection, recurrence of a child glioblastoma patient during treatment of surgery, radiation, and chemotherapy (Yellow arrow: Tumor mass): $\mathbf{a}$, pre-operation (sagittal view), showing the characteristic appearance of the tumor; $\mathbf{b}$, Immediate postsurgery (sagittal), showing the removal of the tumor; $\mathbf{c}$, 3month post-surgery (sagittal), showing recurrence of the tumor; $\mathbf{d}$, agarose gel electrophoretic analysis of CD133 expression using RT-PCR. The adult patient: Pre- and post-operative magnetic resonance imaging (MRI) shows hemorrhage and involvement of the lateral ventricle (e, f). e: Preoperative MRI (Gadolinum-enhanced) of previous intracerebral hemorrhage (before tumor operation). f: Post-operative MRI. g: Pathology photomicrographs showed typical glioblastoma multiforme with nuclear atypia, endothelial proliferation, and necrosis (hematoxylin and eosin stain). Necrosis was seen with the pseudopalisading pattern of malignant cells. This is a high-grade glia neoplasm, characterized by variably cellular patternless sheets of polygonal and fusiform cells with moderate to marked nuclear atypia, amphophilic cytoplasm, prominent nucleoli, and many mitotic figures. Irregular zones of geographic necrosis were surrounded by palisading neoplastic cells. The tumor was vascular with many blood vessels lined by plump endothelial cells interspersed within the glial component. The cellular areas of the neoplasm are merged gradually with adjacent cerebral cortex. Neuronal satellitosis was seen in the transitional zone. These are consistent with glioblastoma multiforme involving intraventricular zone.

malignant glioma (see below). Dissection was continued initially laterally and inferiorly, and fully developed a plane between the white matter and what appeared to be tumor. The medial dissection was carried to the falx, as directed by the MRI data. A deep plane and more superior plane in a circumferential manner following up the white matter and tumor plane were made. Bipolar electrocautery as well as suction were used following dissection. The occipital horn of the lateral ventricle on the left side was entered and an external ventricular drain was placed through the opening. Further inspection showed excellent hemostasis and gross total resection seemed to have been achieved.

Postoperative MRI (Figure 1f) showed surgical changes involving the left parieto-occipital lobe. There was a large cystic area identified at the operative site, as seen on the T1-weighted images. Surgical removal of the large, mixed, cystic (solid) mass in the left parieto-occipital lobe resulted in a fluid collection which measured $4.6 \times 4.9 \mathrm{~cm}$ at the operative site. There was a decrease in the amount of vasogenic edema and mass effect and a decrease in the shift of the midline toward the right as well as a decrease of the mass was seen on the left lateral ventricle.

\section{Pathological analysis determined high-grade glioma}

Frozen section diagnosis of the left occipital brain tumor was consistent with malignant glioma. Microscopically, the occipital tumor showed a high-grade glial neoplasm (Figure 1g). It was characterized by variably cellular, patternless sheets of polygonal and fusiform cells with moderate to marked nuclear atypia, amphophilic cytoplasm, prominent nucleoli, and numerous mitotic figures (Figures 1g). Irregular zones of necrosis were surrounded by palisaded neoplastic cells. The tumor was vascular, with many blood vessels lined by plump endothelial cells interspersed within the glial component. The cellular areas of the neoplasm were merged gradually with nearby cerebral cortex; and neuronal satellitosis was noted within the transitional zone. A strong, positive, glial fibrillary acidic protein (GFAP) stain was noted. 
Tumor grew back after surgical and adjuvant therapies as monitored by $\mathrm{CT}$ and MRI

Two months after surgery, MRI of the brain, with \& without contrast, showed that, within the region of the left posterior parietal lobe, there was a ring-enhancing cystic area measuring $4.5 \times 3.05 \mathrm{~cm}$. There was vasogenic edema associated with this ring-enhancing cystic area. There was extensive, abnormal, high signal intensity seen within the deep white matter and periventricular distributions bilaterally as well as within the right cerebral hemisphere. There was also increased signal seen within the thalamic region as well as within the internal capsule bilaterally.

Four months postsurgery, CT of the brain showed there was a prominent periventricular area of decreased attenuation. Postoperative changes were seen in the left posterior parietal area. There was a fluid collection noted. There were focal areas of encephalomalacia in the right and left cerebellum. There was ex vacuo dilatation of the posterior horn of the left lateral ventricle. The prominence of the ventricles and sulci was consistent with cortical atrophy. The patient passed away shortly thereafter (six months after the surgery).

\section{Cultured CD133-expressing cells behaved as cancer cells}

A relatively morphologically-homogeneous tissue was obtained after the differential purification procedure (Figure 2A), from which single cells were obtained containing $\sim 0.2 \%$ CD133-positive cells (Figure $2 \mathrm{~B}$ ). The recurrent tumor showed higher CD133 expression than the primary tumor from the same patient (Figure 1d). Single cells were grown into neurospheres under stem cell culture technique (Figure 3). The control was normal NIH3T3 mouse fibroblasts, grown in parallel, which ceased dividing whereas CD133-positive cells continued to proliferate under the otherwise restrictive conditions of soft agar (Figure 4). Although the CD133-positive cells formed colonies in soft agar with similar efficiencies $(80-100 \%)$, the sizes of the colonies varied widely, suggesting they were heterogeneous (Figure 4). There was little colony formation with NIH3T3 cells. The CD133positive neurospheres adhered to fibronectin in serumcontaining medium and spread out (Figure 5) and extended neurite-like processes (Figure 6). These cells expressed certain differentiation markers, such as GFAP and $\beta$-Tubulin-III (Figure 6E). The cells preferred certain adhesion molecules (Figure 6). They grew from fast to slow - Matrigel $^{\mathrm{TM}}(\mathrm{A}) \rightarrow$ Laminin $(\mathrm{C}) \rightarrow$ Collagen IV (B) $\rightarrow$ Fibronectin (D). Cells grew faster with Matrigel ${ }^{\mathrm{TM}}$ (a gelatinous protein mixture secreted by EngelbrethHolm-Swarm mouse sarcoma cells) than with any other single adhesion molecule presumably because Matrigel ${ }^{\mathrm{TM}}$ resembles the complex extracellular environment found in many tissues that contains multiple species of adhesion molecules (Laminin, Entactin, and Collagen) and growth factors as well as other components. Matrigel ${ }^{\mathrm{TM}}$ has been used to maintain the pluripotent, undifferentiated state (self-renewal) and promote stem cell growth and differentiation upon dilution [27].

It has been shown that tissue elasticity regulates stem cell morphology and their lineage specification [28]. On plastic Petri dishes, the CD133+ cells spread out in culture (Figures 5 and 6); however, these dishes provide only an artificial environment. To address this issue, we used an ex vivo organotypic brain slice culture system that allows the CD133-positive cells to grow in cell clumps in the brain-mimicking environment (Figure 7A) while normal neural stem cells spread out to be single cells and underwent extended processes (Figure 7B). The CD133positive cells, therefore, behaved as they did in soft agar (clonogenic formation) as described above and as they did after in vivo transplantation as described below.

\section{Diverse marker expression}

The CD133+ cells were assayed for expression of wellestablished genetic biomarkers for neural stem cells and differentiated neural cells using RT-PCR under different annealing temperatures (Figure 8; Table 1). Medium-level expression of stem cell markers included Nestin, Notch 4, Cav-1, Nucleostemin, EFNB2, EFNB3, and HIFo1 (Figure 8A). Low-level expression of Musashi, DACH1, Notch 1, Notch 3, Cav-2, EFNB1, and EFNB3 was also seen (Figure 8A). The high-level expression genes consisted of CD133 (i), Ki67 (i), MMP13 (vii), Sox2 (i) and Notch2 (viii). We observed that proteoglycans were expressed in the cells cultured in serum-containing medium. Low-level expression biomarkers from the cells in serum-containing medium consisted of Mucin 18 and Cathepsin B (Figure 8B). Medium to high-level expression genes included c-Myc, neural specific endolase (NSE), Mucin 24, TIMP1, and Cathepsin L (Figure 8B). Tumor suppressors and oncogenes (p53, PTEN, c-Myc) were also found to be present in these tumor cells. Some of these biomarkers in the tumor stem cells were found in the side-by-side control normal neural stem cells, including those genes described previously from our group [29].

\section{Caveolin-1 is expressed in the CD133-positive cells}

We have observed, for the first time, that Caveolin-1 mRNA is expressed in CD133-positive cells (Figure 8A). Caveolin-1 is a well-established cancer marker for breast cancer prognostics. We confirmed that consistent with mRNA, Cav-1 protein was expressed in the CD133+ tumor cells by Western blot analysis (Figure 9). Both Cav- $1 \alpha$ and Cav- $1 \beta$ isoforms were expressed in these cells (data not shown), as doublets which previously described in other types of normal cells [30]. 


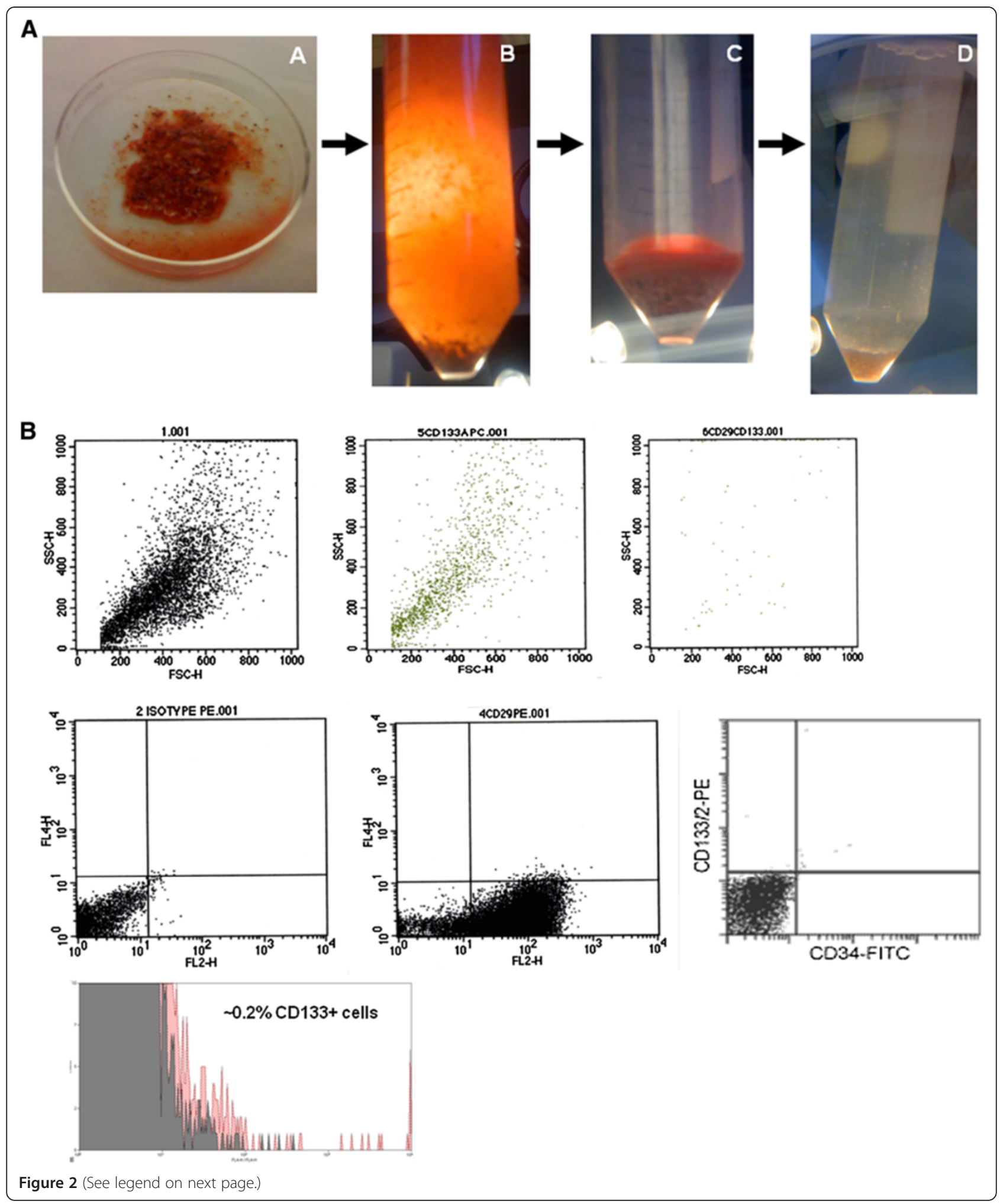

CD133-positive cells formed brain tumors in vivo

To prove the patient's tumor-derived CD133-positive lineage was capable of forming a tumor, we performed stereotactic transplantation of CD-133-positive cells into the brains of immune-deficient NOD/SCID mice. The resulting tumor histology showed nuclear pleomorphism and high mitotic activity (Figure 10), which strongly resembled the histological features of the patient's 
(See figure on previous page.)

Figure 2 Isolation and FACS of tumor cells. A. Procedure for isolation and dissociation of tumor cells into single cells. The tumor specimens were minced by using crossed scalpels to cut them into small pieces over an ice-bath. The minced pieces were triturated with $50-\mathrm{mL}$ and $25-\mathrm{mL}$ pipette, consecutively. The sample was washed 6 X with cold Hank's buffer-saline solution (HBSS) without phenol red and allowed to settle by gravity (3-5 min). The supernatant was transferred to a fresh 50-mL conical polypropylene tube (Falcon, Becton Dickinson) and the precipitate (necrotic tissue [black] and vessel pieces) was discarded. The pieces were washed repeatedly until the supernatant became clear. Remaining red blood cells were removed by step-gradient centrifugation over Histopaque-1077. The pellet was red blood cells and the brain tissue was in the supernatant. The supernatant was washed with HBSS and centrifuged (183 g, $5 \mathrm{~min}, 3 \mathrm{x}$ ) to remove the Histopaque-1077. The pellet was triturated sequentially with $10 \mathrm{~mL}, 5 \mathrm{~mL}$, and $2 \mathrm{~mL}$ pipettes. The suspension was then digested with collagenases, papain, protease, DNase, and Dispase II. The loose cells were washed and the cell pellet was suspended in cell dissociation buffer. B. FACS analysis of tumor cells. The surface marker expression (CD133, CD29, CD34) were used. The antibodies were as for name/synonym/clone: CD29/integrin- $\beta 1 /$ MAR4, CD34/Sialomucin-l/AC136, and CD133-1/Prominin-1/AC133.

original glioblastoma (Figure 1g). All these data combined, therefore, strongly suggested that CD133-positive cells isolated from the GBM tissue mass were cancer stem cells (CSCs).

\section{Discussion}

In this report, we have included: 1) a detailed clinical course, 2) radiological findings, 3) the surgical approach and its results, 4) pathological details, 5) marker expression analysis of tumor cells derived from the CD133positive cells, and 6) evidence for ex vivo and in vivo behavior including tumor-initiating capacity. Clinically, it is of great interest to have a successful isolation of glioblastoma stem cells from a rare GBM that involves the neurogenic ventricular wall. We have found in this rare case that a tumorigenic CD133-positive progenitor cell phenotype is part of the tumor. The mRNA expression of an array of heterotypic biomarkers may explain the course of this patient's clinical outcome as gene expression indicates the participation of unique cancerrelated transcripts specifically related to GBM stem cells, such as caveolin-1 and -2 . Their expression in GBM CSC has not been previously reported in the literature.
GBMs usually form in the cerebral white matter, grow quickly, and can become large before producing symptoms. Malignant tumor cells infiltrate from primary tumor sites to nearby tissues, representing the major cause of death in patients. In the clinic, the intrinsic infiltration of single glioma cells into brain parenchyma renders these cancers resistant to the current treatment of surgical removal in combination with radiation-, chemoand immuno-therapies [31]. Invariable infiltration into adjacent brain parenchyma, crossing commissures to expand to the opposite cerebral hemisphere, is a hallmark of the malignancy of GBM. Thus, despite recent advances in surgical and medical therapy, the prognosis for patients diagnosed with high-grade GBM remains poor. The realization that a self-replication mechanism may be shared by both normal stem cells and cancer cells has led to the new concept of the cancer stem cell (CSC) [6,32]. Similar mechanisms may control normal and cancer stem cell properties. This concept as has been supported by reports that showed the existence of a cancer stem cell population in human brain tumors of both children and adults with different phenotypes [33-35]. Both normal and tumor stem cell populations are heterogeneous with respect to proliferation and differentiation.
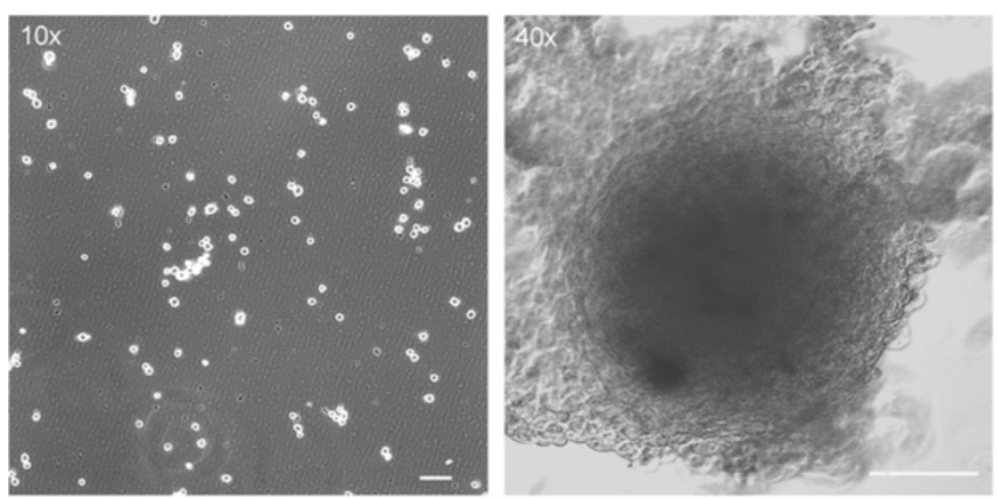

Figure 3 Neurosphere formation was seen with phase-contrast microscopy of GBM CD133-positive tumor cell culture. Single tumor cells were sorted for CD133 expression by magnetic bead cell sorting to collect CD133-positive cells. Single CD133-positive cells were then cultured. Neurospheres were seen when single CD133-positive tumor cells were cultured in EGF- and bFGF-containing, serum-free medium. The left panel is before culture of CD133+ cells (t: 0 day), and the right panel after six weeks (t: 42 days). (Left panel, scale bar $=50 \mu \mathrm{m}$; right panel, scale bar $=100 \mu \mathrm{m})$. 


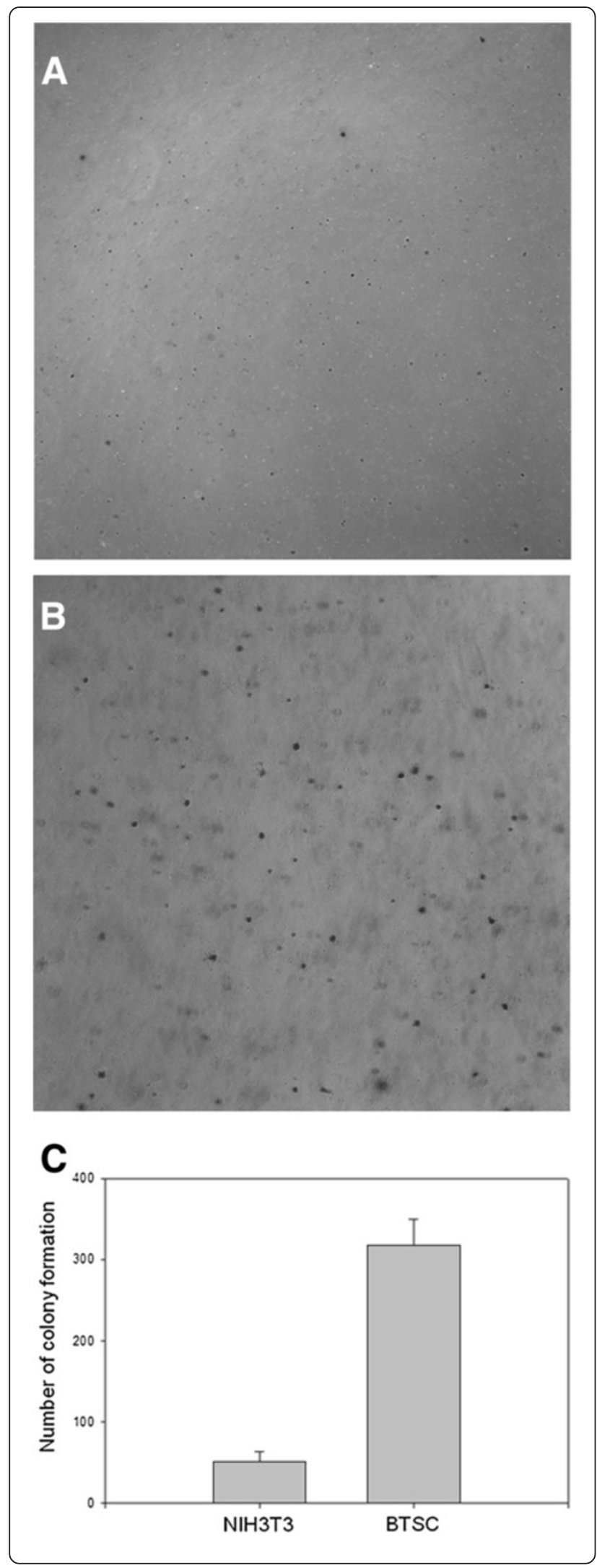

Figure 4 Colonies were seen in clonogenic assay. Growth of normal NIH 3 T3 cells (A) and CD133-positive tumor cells (B) in soft agar shown in micrographs by phase contrast microcopy (4x). C: The numbers of colonies were counted in a view field with the $4 x$ objective at 14 days of culture and plotted in bar graphs from three independent repeats.

The difference between normal neural stem cells and tumor stem cells has not been fully defined $[7,36]$, but it has been speculated that brain tumor stem cells may be a cause of the resistance of tumors to conventional treatments, and high recurrence rate [37-40]. However, targeted elimination of tumor stem cells may be detrimental if it also eliminates normal neural stem cells. In our study, glioblastoma stem cells from a rare GBM that involves the neurogenic ventricular wall may tackle and hijack the source of the normal neural stem cells that reside in neurogenic ventricles.

The hallmark of the malignant glioblastoma is its diverse marker expression. Marker expression in the prognosis of malignant brain tumors has been explored, the main issue being the heterogeneous expression of most of the genes examined [41-50]. We have presented evidence of the successful isolation and characterization of

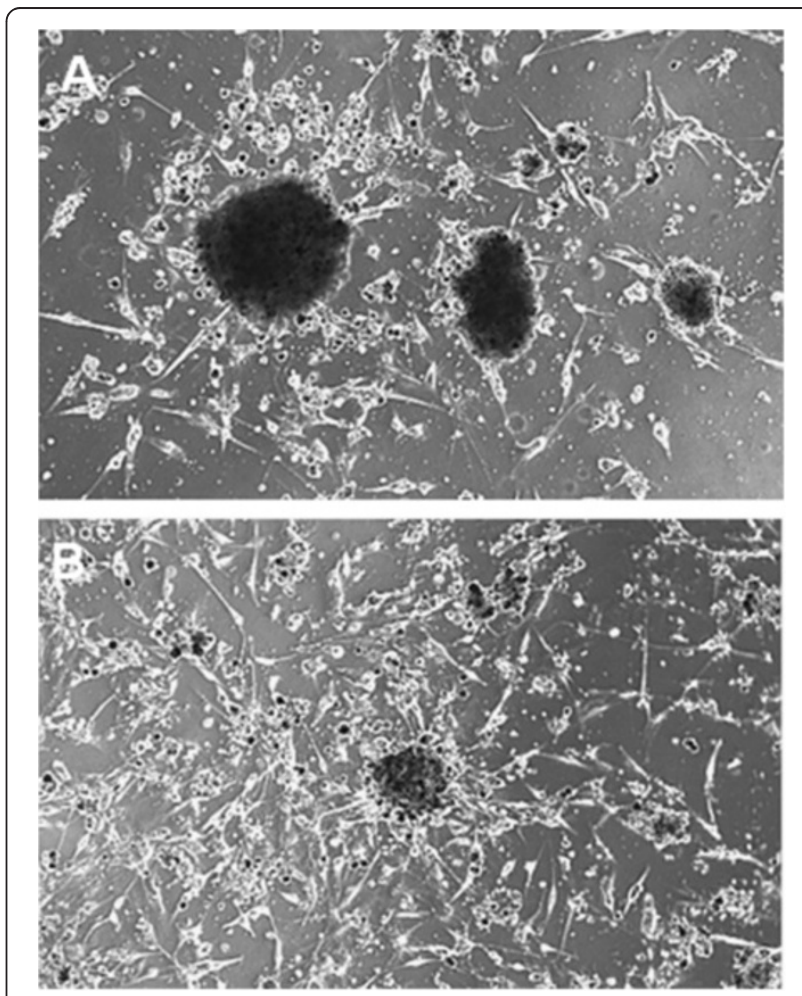

Figure 5 Adherent culture on plastic dishes in serumcontaining medium on fibronectin coated plates. Neurospheres adhered to the plastic surface at day 1 (A) and spread out and grew at day 3 (B). A 10x objective was used for imaging. 

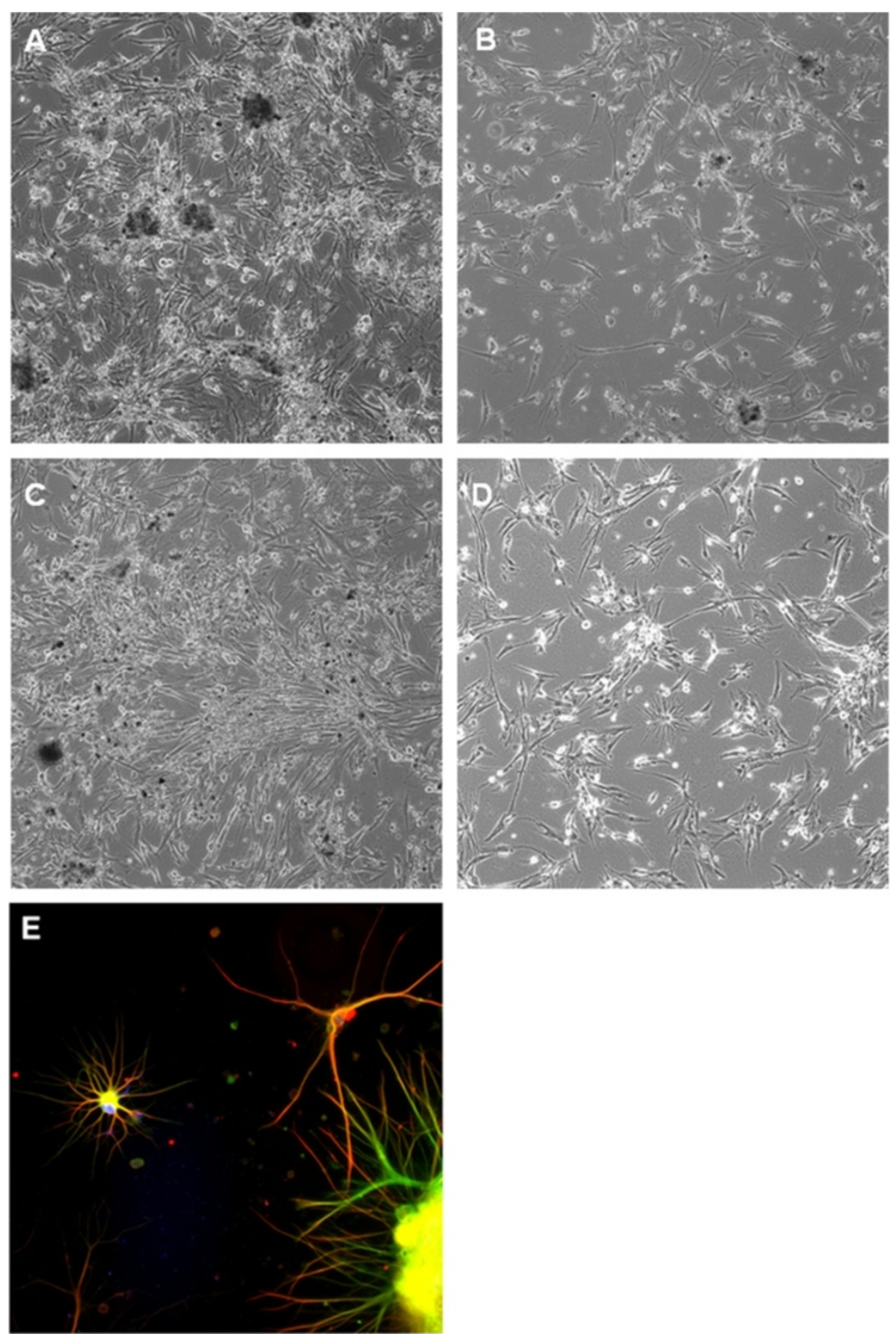

Figure 6 Adherent culture in serum-containing medium on plastic dishes coated with extracellular matrices. A: Coated with Matrige ${ }^{\mathrm{TM}}$. B: Coated with collagen IV. C: Coated with laminin. D: Coated with fibronectin. E: Strong, positive, GFAP stain was noted (in red). Immature neurons positive for $\beta$-Tubulin III (green) were around the neurosphere (lower right) when grown on Matrigel ${ }^{\mathrm{TM}}$ in serum-containing medium. Nuclei were stained blue by Hoechst. (A, B, C, D: 10x objective; E, 20x objectives). The conclusion for panels A, B, C, D is that the cells behave differently in different adhesion molecules coated dishes. They grew in different speeds: from fast to slow - Matrigel ${ }^{\mathrm{TM}}(\mathrm{A}) \rightarrow$ Laminin (C) $\rightarrow$ Collagen IV (B) $\rightarrow$ Fibronectin (D). 

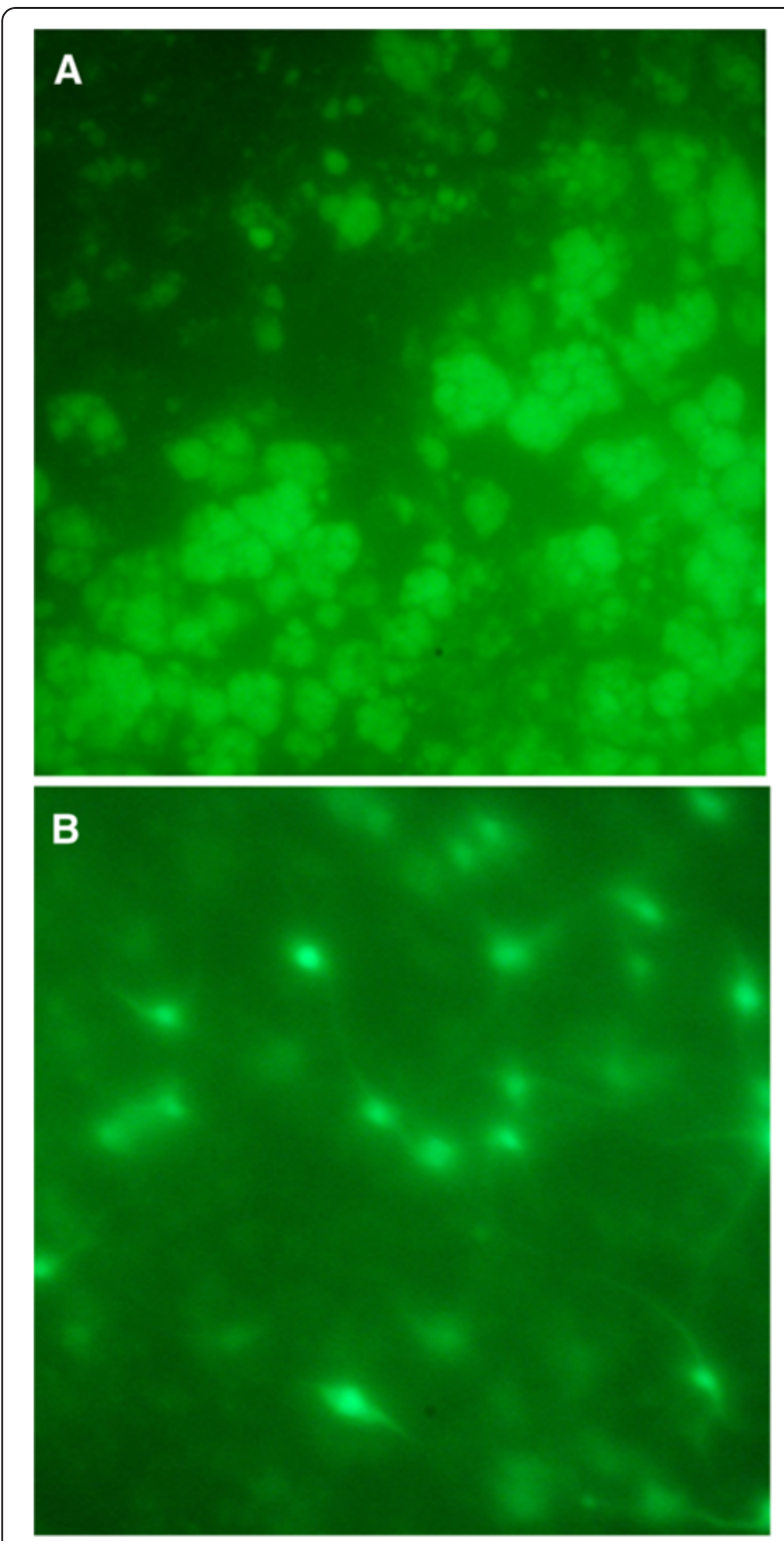

Figure 7 Normal neural stem cells and brain tumor stem cells behaved differently on the organotypic brain slice. All cells were labeled with Lentivirus-GFP and underwent live cell imaging. A: CD133-positive GBM stem cells clumped together. B: Normal neural stem cells spread out and extended processes. (All 20x objective).

a small subpopulation of cancer stem cells. The molecular features of these tumor cells may provide potential new therapeutic targets, and therefore strategies that may control them. Certain molecular markers are consistent with those previously reported [51]. For example, Murat and colleagues (2008) provided the first clinical evidence for the implication of high epidermal growth factor receptor (EGFR) expression associated with resistance to concomitant chemoradiotherapy in a "glioblastoma stem cell" or "self-renewal" phenotype [40].
The clongeneity of these single CD133 positive cells showed biological differences in the growth capacity as shown in Figure 4 and Figure 7. In fact, Dr. Cavenee and Dr. Furnari and colleagues showed that CSCs undergo clonal evolution from a single GBM cancer stem cell to extensive heterogeneity at the cellular and molecular levels [52]. The single-cell generated heterogeneity confers a biological advantage to the tumor by creating an intratumoral and tumor-microenvironment community that serves to maintain the heterogeneous tumor composition and to promote tumor growth. This tumor community allows interactions between CSCs and/or tumor cells and their environment and between different CSCs and /or tumor cell subclones. Those interactions need to balance out. An inbalance may drive tumor growth, drug resistance, immune suppression, angiogenesis, invasion, migration, or more CSC renewal. We suggested that a delicate balance may be modulated by innovative therapeutics to keep the tumor in surveillance check [26]. We thought that in the context of stem cell development, there is a parallel with the concept of quiescent or dormant cancer stem cells (CSCs) and their progeny, the differentiated cancer cells; these two populations communicate and co-exist. The mechanism with which determines to extend self-renewal and expansion of CSCs is needed to elucidate.

CD133 (prominin-1), a neural stem cell (NSC) marker implicated in brain tumors, notably glioblastoma, was highly expressed in our material. Interestingly, CD133 is also expressed in the glioma cell lines U251 and U87MG [53]. Remarkably, a recent study showed that the level of membrane particle-associated CD133 is elevated in early stage glioblastoma patients and decreases dramatically in the final stage of the disease [54]. This change may be used for diagnosing and surveying glioblastoma initiation and progression [55,56]. More clinically relevant, CD133 is associated with specific extracellular membrane particles in cerebrospinal fluid, which can be routinely used for diagnosis and prognosis in neurological diseases. Malignant brain tumors have a higher CD133 index than low-grade tumors [57]. Purified populations of CD133-positive tumor cells injected into the brains of NOD/SCID mice induced tumors that were heterogeneous and had the characteristic of infiltration [58,59]. It has also been shown that transplantation of neurospheres derived from glioblastoma tumor cells cultured in EGF and bFGF-containing media drove tumor formation in immune-deficient mouse models [60,61]. These CD133-positive tumor cells may be a leading force for reinitiating tumor genesis and progression [62]. However, there is debate about the lineage relationship between normal NSCs and brain cancer stem cells. It is not yet fully understood if CD133-positive brain CSCs are derived from CD133-positive normal NSCs. Thus, it 


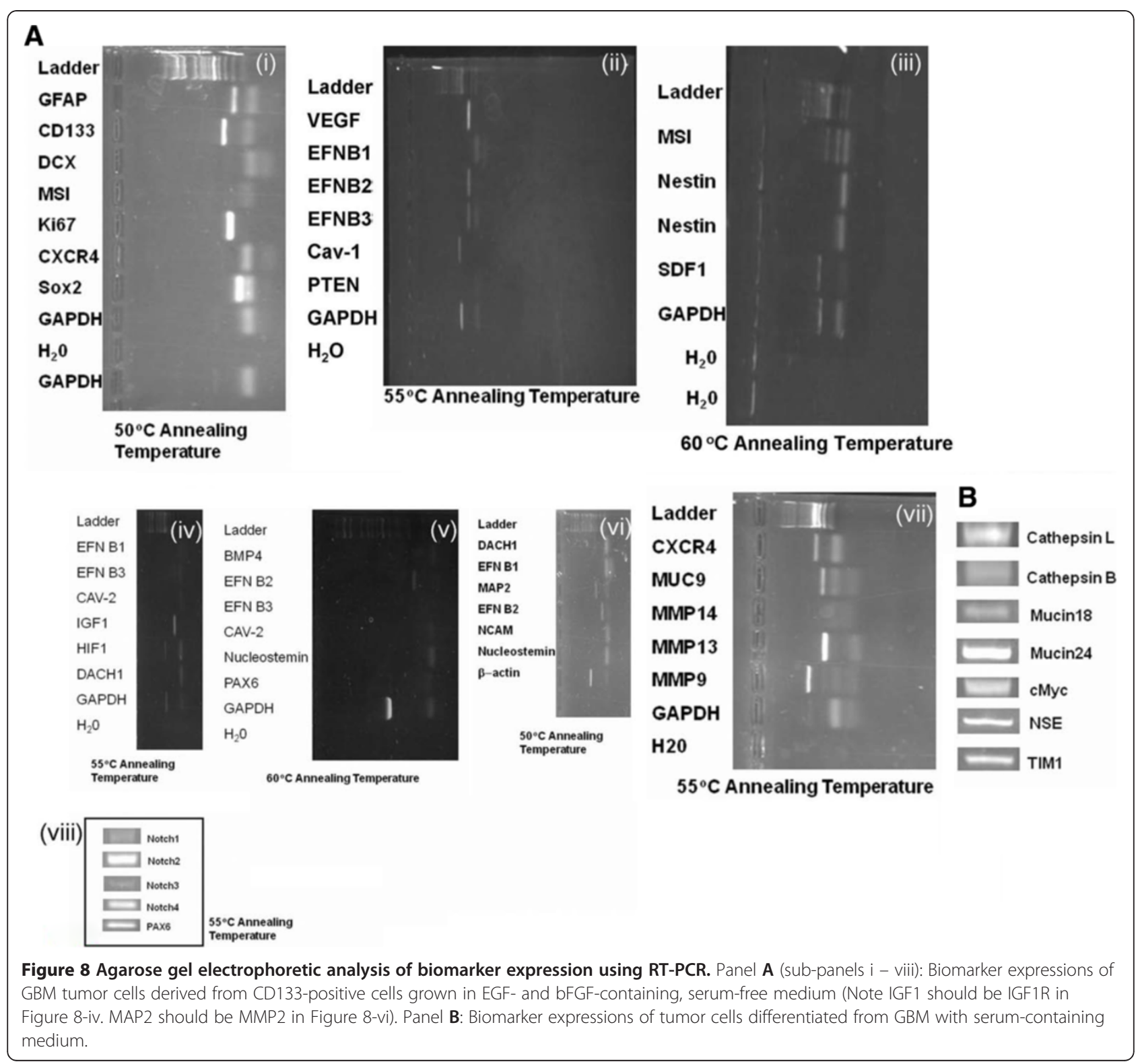

is still questionable if tumor therapies can be developed for targeted destruction of CSCs without damaging normal NSCs. Dr. Bota and colleagues have recently found that both the proteasome inhibitor bortezomib (BTZ) and the epidermal growth factor receptor tyrosine kinase inhibitor erlotinib (ERL) decreased glioma stem-like cells (GSCs) proliferation but not NSC viability [63]. Surprisingly, commonly used temozolomide (TMZ) and cisplatin (CIS) were more toxic for NSCs than for GSCs. This in vitro observation may inspire a new journey to search for GSC-specific destruction agents, which are not detrimental to NSCs.

Angiogenesis is a critical component of brain tumor growth. Consistent with our pathological findings, VEGF is highly expressed, confirming that neovasculization is driven by the up-regulation of VEGF around tumors. Recent clinical trials of antivascular endothelial growth factor agents for glioblastoma show promising progression-free and better overall survival rates, even without inhibiting tumor growth [64].

The intermediate filament protein, Nestin, and the RNA-binding protein, Musashi, are expressed by NSCs during CNS development. Their expression in glial tumors correlated with the levels of Cysteine Cathepsins [65] that are known as prognostic markers of several tumors [41]. Nestin is a strong prognostic marker of glioma malignancy; the invasive cells may well be closely related to glioma stem cells [41], which our data confirms. Nestin functions in the organization of the cytoskeleton, cell signaling, organogenesis, and cell metabolism. It is down- 
Table 1 Summary of marker expression determined by RT-PCR

\begin{tabular}{|c|c|c|c|}
\hline \multicolumn{2}{|l|}{ Stem cell markers } & \multicolumn{2}{|c|}{ Proliferation, angliogenic, migration markers, growth factors, adhesion } \\
\hline SOX2 & ++++++ & Ki67 & +++++ \\
\hline DACH1 & + & VEGF & +++ \\
\hline CD133 & ++++ & HIF1 & + \\
\hline Nestin & +++ & CXCR4 & ++ \\
\hline \multirow[t]{3}{*}{ Nucleostemin } & ++++ & SDF1 & + \\
\hline & & IGF1R & ++ \\
\hline & & NCAM & +++ \\
\hline Glial Cells & & PAX6 & ++++ \\
\hline \multirow[t]{2}{*}{ GFAP } & ++ & & \\
\hline & & \multicolumn{2}{|c|}{$\underline{\text { Ephrins receptors and ligands (cell repulsion, adhesion, migration) }}$} \\
\hline Neuronal & & EphB1 Receptor & $\mathrm{n} / \mathrm{a}$ \\
\hline DCX & + & EphB2 Receptors & ++++++ \\
\hline MSI & + & EphB3 Receptors & +++++ \\
\hline MAP2 & + & EFNB1\ & + \\
\hline Neural Specific Endolase & ++++ & EFNB2 & ++ \\
\hline \multirow[t]{3}{*}{ Beta-3Tubulin III } & + & EFNB3 & + \\
\hline & & MMPs, Peptidases & ++ \\
\hline & & MMP2 & +++ \\
\hline Tumor Suppressors/Oncogenes & & TIMP1 & \\
\hline p53 & + & MMP9 & +++ \\
\hline PTEN & + & MMP13 & ++++ \\
\hline Bmi-1 & ++ & MMP14 & + \\
\hline CAV-1 & ++ & Cathepsin B & + \\
\hline CAV-2 & + & Cathepsin L & +++ \\
\hline \multirow[t]{2}{*}{ c-Myc } & +++ & & \\
\hline & & Controls & \\
\hline Proteoglycans & & GAPDH & +++ \\
\hline Mucin9 & ++ & Beta-Actin & ++ \\
\hline Mucin18 & + & $\mathrm{H}_{2} \mathrm{O}$ & \\
\hline Mucin24 & ++++ & & \\
\hline \multicolumn{4}{|l|}{ Notch-Family } \\
\hline Notch1 & + & & \\
\hline Notch2 & +++ & & \\
\hline Notch3 & + & & \\
\hline Notch4 & ++ & & \\
\hline
\end{tabular}

regulated in mature cells, whereas GFAP, neurofilaments, and PDGFR are expressed in differentiated astrocytes, neurons, and oligodendrocytes, respectively [66]. Neoplastic transformation up-regulates Nestin expression in astrocytes of the adult CNS, suggesting that its reactivation may relate to tumor genesis [67]. Nestin has been shown to be a strong prognostic marker for glioma malignancy and its expression correlates with patient survival [68]. We have found Nestin expressed in both CD133-positive tumor cells and differentiated tumor cells, although the latter with down-regulation, which suggests the existence of residual neural stem cells after induced differentiation.

Peptidases hydrolyze macromolecular components of the extracellular matrix, support the malignant invasive behavior of brain tumor cells, and promote brain tumor progression by advancing tumor angiogenesis [69-71]. Peptidases consist of matrix metalloproteinases (MMPs), Cathepsins, and Plasminogen activators. Among MMPs, 


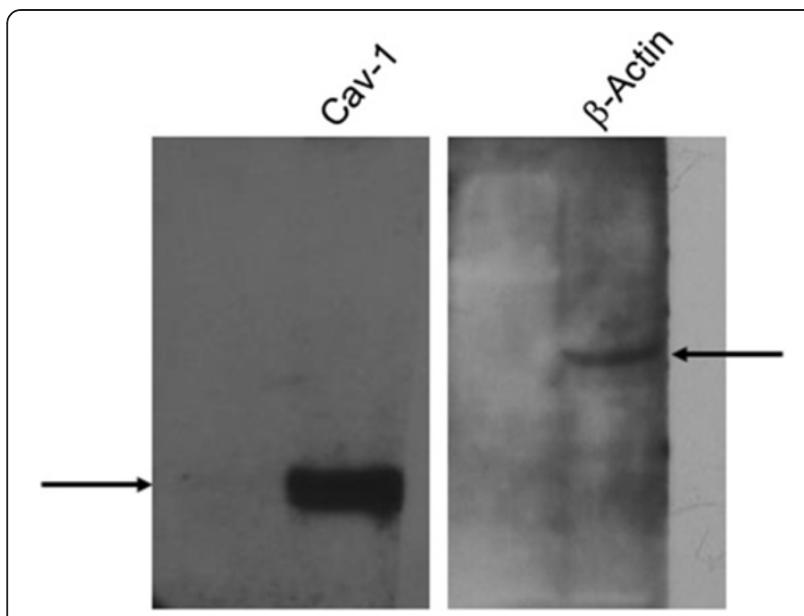

Figure 9 Western blot analyses of GBM cells cultured with serum-free medium. Cells were grown as described in Methods section and the lysate proteins were subjected to SDS-PAGE. The sample was subjected to immunoblot analysis with caveolin-1 mouse monoclonal antibody (4 H312, sc-70516; Santa Cruz Biotech) probe. Note that anti-Caveolin-1 mAb specifically binds to Caveolin1 isoforms (21-24 kDa) while anti- $\beta$-Actin antibody specifically recognizes $\beta$-Actin $(42 \mathrm{kDa})$. These results further demonstrate that Caveolin-1 is present at both the protein level and mRNA level (Figure 8).

MMP2 and MMP9 strongly correlate with glioma progression [72-74]. Most importantly, Wong and colleagues found that increased cerebrospinal fluid (CSF) MMP-9 activity could be a biomarker of disease activity in patients with malignant gliomas, before any changes

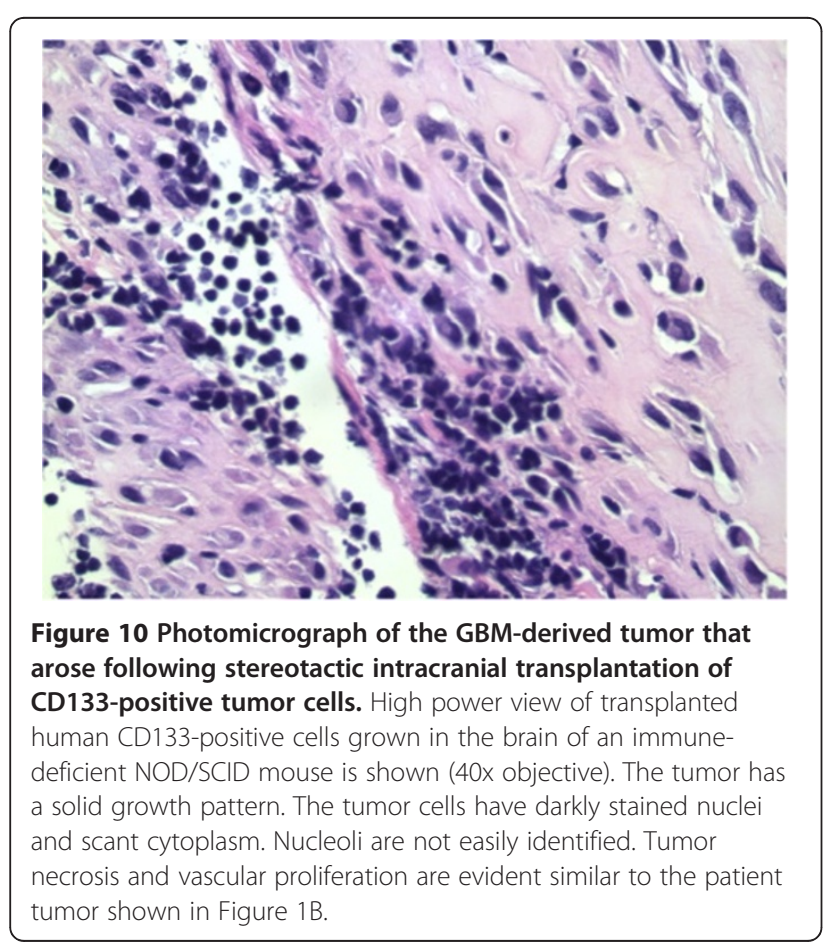

are detectable on MRI [75]. Lysosomal Cathepsin B is highly expressed in malignant glial cells and endothelial cells of vascularized glioblastoma, an indication of a shorter survival time. Besides invasion, Cathepsin L may play a role in decreased susceptibility of anaplastic glioma cells to apoptosis [76,77]. Cathepsin B has been considered a marker for malignancy in the more aggressive type of meningiomas [78]; developing inhibitors of these peptidases might help control local spread [70,77].

Originally identified as an oncogenic partner of c-Myc in murine lymphoma genesis, Bmi- 1 is a member of the polycomb group transcriptional repressors $[79,80]$. Bmi1 , a proto-oncogene for inhibition of p53 involved in cell cycle and self-renewal, is required for the postnatal maintenance of stem cells in multiple tissues, including the central nervous system (CNS) and peripheral nervous system (PNS). Bmi-1 was highly expressed in the GBM tumor cells we cultured from our case, consistent with a previous report [34]. Targeting of the Bmi-1 in stem cells by microRNA-128 inhibits glioma proliferation and self-renewal, implying that miRNA-128 may be a therapeutic target agent for the "stem cell-like" characteristics of glioma [81].

Finally, we have found that Caveolin-1 and Caveolin-2 are expressed in our CD133-positive lineage (Figure 8, Figure 9). Interestingly, their expression in GBM CSCs has not been previously reported in the literature. Rather, this has been reported in commercialized glioma non-stem cell lines, such as glioblastoma cell line U87MG [82]. However, their clinical significance in brain tumor diagnosis and prognosis remains to be determined. Caveolin-1 has been found in detergentresistant plasma membrane microdomains involved in signaling transduction in many cell types, including neurons and astrocytes [83-85]. It is a secreted biomarker in some pathological conditions [86]. In prostate cancer, high preoperative serum Caveolin-1 levels have been established as a biochemical predictor of cancer progression and recurrence [87], suggesting a poor prognosis (shorter time to cancer recurrence). Lisanti's group analyzed breast tissue samples from 154 women diagnosed with breast cancer using immunohistochemical staining of stromal Caveolin-1 [88]. Among each subgroup of patients, as grouped by prognostic factors such as hormone status, disease stage or lymph node status, a loss of stromal Caveolin-1 remained the strongest single predictor of breast cancer patient outcome. Progressionfree survival (PFS) was also affected by the loss of stromal caveolin-1. The approximate 5-year survival rate for patients positive for stromal Caveolin-1 was $80 \%$ vs. $7 \%$ for patients negative for stromal caveolin-1, i.e. a $\sim 11$.5-fold reduction in 5-year PFS. Caveolin-1 serves not only as a prognostic marker, but also as a means of therapeutic stratification. Caveolin-1 can be detected at 
breast cancer diagnosis, which is important because high-risk patients would benefit from more aggressive antiangiogenic therapy. A prognostic biomarker present in the stroma rather than the epithelial cancer cell is a paradigm-shift, since a diagnostic test may not require DNA-based technologies for cost-effective identification for high-risk breast cancer patients at diagnosis.

Despite their clinical importance, little is known about the underlying composition and cellular interactions of tumors that govern their degree of malignancy, and consequently, provide targets to control their growth. The diverse biomarker expression reflects the nature of heterogeneity in the tumor, a mixture of cells at different stages of their development. Indeed, Vescovi's group discovered that at least two types of CSCs bear quite diverse tumorigenic potential and distinct genetic anomalies, yet derive from common ancestor cells within different regions of the same human GBM [89]. Thus, therapeutic success relies on an effective strategy to select for a therapy to target some particular stage of tumor cell development at which tumor cells are most susceptible to treatment.

The transition from neural stem cells to cancer cells [25] may be activated by expression of some cancer driver, characteristic of dominant clones (single cells), but not in every cell [26]. Cancer cell phenotypes may be derived from such a few dominant single cells with a continuum from single driver stem cells to cancer cells. We may need to define at what point we call it a cancer cell, for which a treatment is needed. Such a point of time in cancer development, namely the therapeutic window [90], may be defined by an integrated genomic [91] and epigenomic [92,93] analyses through applying next-generation sequencing technology. However, the current whole-genome sequencing mainly on the bulk tumor that also includes stromal and immune cells, does not specifically address the tumor-initiating cells (or CSCs). Developing therapeutic window-specific drugs may be realized by using patient-specific cancer stem cell lines for chemical and genetic screens as described previously [94]. We need to focus on these tumorinitiating cells at a single-cell level. Glioma stem cell lines derived from patients like the one described in our study may be used for single cell analyses.

\section{Conclusions}

The tumor-forming, CD133-positive cancer stem cells (CSCs) identified from a brain tumor involving the neurogenic lateral ventricular wall may drive the rapid recurrence of the tumor. Determination of mechanisms which enhance self-renewal and expansion of the CSCs may help elucidate novel therapeutic strategies specific control of tumors.

\section{Methods}

\section{Patient's background}

The enrolled patient gave written informed consent to the surgical and experimental procedures as well as to publications of this case report and any accompanying images. The protocol and consent were approved by our Institutional Review Board.

History of present illness: An adult, left-handed, white male had complained of progressive right-sided weakness as well as a decrease in mentation. Serial computed tomographic (CT) imaging showed persistent edema in the left parietofrontal region, with a left parietal intracerebral hemorrhage. Over four weeks, he had decreased mentation and speech. His right side also became much weaker. The neurological examination showed facial weakness, right worse than the left. Motor examination showed right-side poor coordination with pronator drift and about $2 / 5$ motor strength (left side was 4 to $4+/ 5$ ). Sensory systems appeared to be intact, but he was hyporeflexic throughout.

CT scan of the brain without contrast, two weeks after presentation, showed extensive edema that appeared as a hypodense area. The hypodensity had increased in size in the left region as confirmed with magnetic resonance imaging (MRI).

\section{Surgery}

Stereotactic craniotomy was performed and the left-side ventricle occipital horn tumor was debulked. There were no complications with the procedure.

\section{Tumor histology}

Tumor samples were obtained during surgery. Formalinfixed, paraffin-embedded tissue blocks were prepared from the tumor specimen and hematoxylin and eosinstained sections were reviewed by certified pathologists.

\section{Tumor cell culture}

Some of the tumor was used for live cell isolation. The procedure for isolation of neural progenitor cells was followed as described previously by us $[29,95,96]$ and others [34,57,97], with an added step for clearing red blood cells and necrotic cells [98]. Briefly, tumor specimens were minced by using crossed scalpels to cut them into small pieces over an ice-bath. The minced pieces were triturated with $50-\mathrm{mL}$ and $25-\mathrm{mL}$ pipette, consecutively. The sample was washed 6X with cold Hank's buffer-saline solution (HBSS) (Invitrogen, Carlsbad, CA) without phenol red and allowed to settle by gravity (3-5 min). The supernatant was transferred to a fresh 50-mL conical polypropylene tube (Falcon, Becton Dickinson) and the precipitate (necrotic tissue [black] and vessel pieces) was discarded. The pieces were washed repeatedly until the supernatant became clear. Remaining 
red blood cells were removed by step-gradient centrifugation (183 g, 5 min) over Histopaque 1077 (Sigma, St. Louis, MO) [98]. The pellet was red blood cells and the brain tissue was in the supernatant. The supernatant was washed with HBSS and centrifuged (183 g, $5 \mathrm{~min}, 3 \mathrm{x}$ ) to remove the Histopaque-1077. The pellet was triturated sequentially with $10 \mathrm{~mL}, 5 \mathrm{~mL}$, and $2 \mathrm{~mL}$ pipettes. The suspension was then digested with collagenases, papain, protease, DNase, and Dispase II. The sample was washed and the cells were triturated with 1-mL pipette. The loose cells were suspended in cell dissociation buffer (Invitrogen, Carlsbad, CA).

Part of the above cells were analyzed by flow cytometry using a Becton Dickinson FACS Calibur (Franklin Lakes, New Jersey, USA) for surface marker expression (CD133, CD29, CD34). All the antibodies used in this study were obtained from BD Pharmingen (name/synonym/ clone: CD29/integrin- $\beta 1 / M A R 4, C D 34 / S i a l o m u c i n-I / A C 136$, and CD133-1/Prominin-1/AC133). The rest of the cells were sorted by magnetic-activated cell sorting (MACS) with the Indirect CD133 MicroBead Kit (Miltenyi Biotec GmbH, Germany).

Viability of single cells was determined using the fluorescein diacetate (FDA)/propidium iodide (PI) assay [99101]. For serum-free cell culture, $4 \times 10^{4} \mathrm{CD} 133$-positive cells were resuspended in $5 \mathrm{ml}$ of DME/F12 containing 10\% BIT 9500 supplement (Stem Cell Technology), 1x N2 supplement, $20 \mathrm{ng} / \mathrm{mL}$ EGF, $20 \mathrm{ng} / \mathrm{mL}$ bFGF, $2 \mu \mathrm{g} / \mathrm{mL}$ heparin plus an antibiotic cocktail and plated into an uncoated $60-\mathrm{mm}$ dish where they formed neurospheres. The antibiotic cocktail contained $10,000 \mathrm{U} / \mathrm{mL}$ penicillin G, $10,000 \mu \mathrm{g} / \mathrm{mL}$ streptomycin sulfate, $2.5 \mu \mathrm{g} / \mathrm{mL}$ amphotericin $\mathrm{B}, 10 \mu \mathrm{g} / \mathrm{mL}$ gentamicin sulfate, and $10 \mu \mathrm{g} / \mathrm{mL}$ ciprofloxacin (antimycoplasma). Part of the cells were grown in extracellular matrix-coated plates with serum-containing culture medium (Advanced-DME [Adv-DME]; Invitrogen, Carlsbad, CA) containing 5\% FBS plus the antibiotic cocktail to induce differentiation. The extracellular matrices used for coating plates included collagen IV, fibronectin, laminin, and Matrigel. Part of CD133+ cells was cultured in 96-well plate for single-cell culture to form single cellderived neurospheres.

\section{Clonogenic assay}

The clongenic assay used was described previously [102]. Briefly, for testing cell growth in soft agar, $10^{3}$ cells dissociated from neurospheres were suspended in $3 \mathrm{ml}$ Adv-DME containing 5\% FBS and 0.33\% Sea Plaque low-melting-temperature agarose (American Bioanalytical, Natick, MA, USA). The cells were then plated onto $60-\mathrm{mm}$ plates over a 2-ml layer of solidified Adv-DME containing 5\% FBS and 0.5\% agarose, and allowed to settle to the interface between these layers at $37^{\circ} \mathrm{C}$. After $20 \mathrm{~min}$, plates were allowed to harden at room temperature for $30 \mathrm{~min}$ before being returned to $37^{\circ} \mathrm{C}$. The plates were fed every $3-4$ days by overlaying with $2 \mathrm{ml}$ of medium containing 0.33\% agarose. After 2 weeks, the plates were stained with $0.1 \%$ crystal violet in 50 (vol/vol) Methanol. Plates were destained with cold water. Colonies were photographed under $4 \mathrm{x}$ magnification and counted. Multiple plates were used for statistical analyses. NIH 3 T3 cells were used as a control.

\section{Preparation of organotypic slices from murine brain tissue}

Animal protocols were approved by the IACUC. Organotypic brain slices (OTS) were prepared from 8-17day-old neonatal mice (CD-1, Charles River, Wilmington, MA) by modifying our previously published procedure [103]. Briefly, mice were euthanized in a $\mathrm{CO}_{2}$ chamber and then sterilized with a 70 alcohol solution. After cardiac perfusion with saline solution, the mouse was decapitated with surgical scissors and brains were removed with surgical knives and tweezers and placed in Adv-DME on ice. Each brain was then embedded in 4 LMT agarose (Invitrogen), and glued to the cutting stage of the vibratome (VT100S, Leica, Wetzlar, Germany). Slices ranging between $200-300 \mu \mathrm{m}$ in thickness were generated with the vibratome and washed 3 times in HBSS to remove any tissue debris and any potentially toxic substances (e.g. excitatory amino acids). The slices were then placed on culture plate inserts $(0.4 \mu \mathrm{m}$ Millicell-CM, Millipore) in sterile-filtered slice culture medium (SCM). SCM was prepared by mixing 50 Minimal Essential Medium (Invitrogen), 25 heat-inactivated horse serum (Invitrogen, Carlsbad, CA), 25 mM HEPES, $25 \mathrm{HBSS}, 6.4 \mathrm{mg} / \mathrm{ml}$ glucose, $0.5 \mathrm{mM}$ glutamine, $10 \mathrm{ng} / \mathrm{mL}$ of insulin-like growth factor (IGF), and 1 penicillinstreptomycin-glutamine (Invitrogen). One $\mathrm{mL}$ of SCM was added to each OTS culture and the OTS was incubated at $37^{\circ} \mathrm{C}$ and $5 \mathrm{CO}_{2}$.

\section{Transplantation of cells onto organotypic brain slices}

After 2 days in culture, the OTS was gently washed three times with SCM. CD133-positive cells or neural stem cells (SC27, Refer to [29]) were labeled with a lentivirus construct carrying the GFP gene (Gift from Dr. Wange Lu, University of Southern California). The GFPlabeled cells $\left(200 \sim 10^{3}\right.$ cells in $\left.0.2 \mu \mathrm{L}\right)$ were deposited onto the surface of the OTS. After 6 hours, the slices were washed with SCM to remove unattached cells. Cells engrafted in a week and differentiated in 4 to 7 weeks on OTS.

\section{Semi-quantitative RT-PCR}

The method and primers used specifically for stem cells were previously described by us [104]. Briefly, $1 \mu \mathrm{g}$ of total RNA was subjected to RT-PCR. Twenty-five rounds 
Table 2 Primer design: oligo nucleotide sequences

\begin{tabular}{|c|c|}
\hline Gene & Sequences (5' to $\left.3^{\prime}\right)$ \\
\hline Beta-Actin F & GCACCACACCTTCTACAATGAGC \\
\hline Beta-Actin R & TTGAAGGTAGTTTCGTGGATGCC \\
\hline Beta-tubulin III F & AACGAGGCGCTCTACGACATC \\
\hline Beta-tubulin III $R$ & СTCCTCCTCGTCGTCTTCGTA \\
\hline Bmi-1AS & CATTGCTGCTGGGCATCGTAAG \\
\hline Bmi-1 S & GGAGACCAGCAAGTATTGTCCTITG \\
\hline BMP4 F & GTGAGGAGCTTCCACCACGA \\
\hline BMP4 R & ACTGGTCCCTGGGATGTTCTC \\
\hline Cathepsin B F & GCAGCCTCAGCCACCCAGAT \\
\hline Cathepsin B R & CCACCATTACAGCCGTCCCCACAC \\
\hline Cathepsin LF & CCGGGGAGGGCAGTTGAG \\
\hline Cathepsin LR & CCTTGAGGCCCAGAGCAGTC \\
\hline Cav-1 F & GGACATCTCTACACCGTTCCC \\
\hline Cav-1R & TTATATTCTTTCTGCAAGTT \\
\hline Cav-2 F & ATGGGGGCTGGAGACGGAGAAG \\
\hline Cav-2R & TCAATCCTGGCTCAGTTGCAG \\
\hline CD133 AS & ACGCCTTGTCCTTGGTAGTGTTG \\
\hline CD133 S & CTGGGGCTGCTGTTTATTATTCTG \\
\hline$c-M y c F$ & AAGGTCAGAGTCTGGATCAC \\
\hline$c-M y c R$ & TAACTACCTTGGGGGCCTTI \\
\hline CXCR4 F & CACCGCATCTGGAGAACCA \\
\hline$C X C R 4 R$ & GCCCATTTCCTCGGTGTAGTT \\
\hline Dach1 S & AGGCTTTCGACCTGTTCCTGAA \\
\hline Dach1 AS & GCTGTCAGACCTGTTGGTGGAA \\
\hline$D C X A S$ & GTTCCCTTCATGACTCGGCA \\
\hline$D C \times S$ & AATCCCAACTGGTCTGTCAAC \\
\hline EPHBIS & GAGATGGACAGCTCCAGAGG \\
\hline EPHB1 AS & CCAGCATGAGCTGGTGTAGA \\
\hline EPHB2 S & AAAATTGAGCAGGTGATCGG \\
\hline EPHB2 AS & TCACAGGTGTGCTCTTGGTC \\
\hline EPHB3 S & AGCAACCTGGTCTGCAAAGT \\
\hline EPHB3 AS & TCCATAGCTCATGACCTCCC \\
\hline EFNB1 S & GGAGGCAGACAACACTGTCA \\
\hline EFNB1 AS & GAACAATGCCACCTTGGAGT \\
\hline EFNB2 S & GCAAGTT-CTGCTGGATCAAC \\
\hline EFNB2 AS & AGGATG-TTGTTCCCCGAATG \\
\hline EFNB3, S & CTGAAATGCCCATGGAAAGA \\
\hline EFNB3, AS & ACGCCCAGCAAGAGCAGCGC \\
\hline GAPDHS & ACCACAGTCCATGCCATCAC \\
\hline GAPDH AS & TCCA CCACCCTGTTGCTGTA \\
\hline GFAP S & ACATCGAGATCGCCACCTAC \\
\hline GFAPAS & ACATCACATCCTTGTGCTCC \\
\hline HIF1 S & GTCGGACAGCCTCACCAAACAGAGC \\
\hline HIFI AS & GTTAACTTGATCCAAAGCTCTGAG \\
\hline IGFIRS & ACGCCAATAAGTTCGTCCAC \\
\hline
\end{tabular}

Table 2 Primer design: oligo nucleotide sequences (Continued)

\begin{tabular}{|c|c|}
\hline IGFIR AS & TCCATCCTTGAGGGACTCAG \\
\hline Ki67 F & GGAGGCAATATTACATAATTTCA \\
\hline Ki67 R & CAGGGTCAGAAGAGAAGCTA \\
\hline MMP2 F & CCA CGT GAC AAG CCC ATG GGG CCC C \\
\hline$M M P 2 R$ & GCA GCC TAG CCA GTC GGA TाT GAT G \\
\hline MMP9 F & CAACATCACCTATTGGATCC \\
\hline MMP9 R & CGGGTGTAGAGTCTCTCGCT \\
\hline MMP13 F & TGCTCGCATTCTCCTTCAGGA \\
\hline MMP13 R & ATGCATCCAGGGGTCCTGGC \\
\hline MMP14 F & CGCTACGCCATCCAGGGTCTCAAA \\
\hline MMP14 R & CGGTCATCATCGGGCAGCACAAAA \\
\hline msil s & GAGACTGACGCGCCCCAGCC \\
\hline msil AS & CGCCTGGTCCATGAAAGTGACG \\
\hline Mucing F & CATGACCGGTGGACTITTCT \\
\hline Mucing $R$ & TCCTGTGAACCTTTCCCAAC \\
\hline Mucin18 F & GTGTTGAATCTGTCTTGTGAA \\
\hline Mucin18 R & ATGCCTCAGATCGATG \\
\hline Mucin24 F2 & GTTAATACTACCTGCTITTGGATAGAATGT \\
\hline Mucin24 R2 & CCACTTGACAATCACTAACTGTTGAG \\
\hline NCAM1 AS & GGTGTTGGAAATGCTCTGGT \\
\hline NCAM1S & AGGAGACAGAAACGAAGCCA \\
\hline Nestin & GGCAGCGTTGGAACAGAGGTTGGA \\
\hline Nestin $R$ & CTCTAAACTGGAGTGGTCAGGGCT \\
\hline Notch1 F & TGTTAATGAGTGCATCTCCAA \\
\hline Notch1 R & CATTCGTAGCCATCAATCTTGTCC \\
\hline NSE AS & GACAGTTG CAGGCCTTTCTTC \\
\hline NSE S & CATCGA CAAGGCTGGCTACACG \\
\hline Nucleostamin F & CATGACCTGCCATAAGCGGT \\
\hline Nucleostamin $R$ & CAATTACTCCAACCCGAATGGC \\
\hline Pax6 F & GAGCCTCATCTGAATCTTCTCCG \\
\hline Pax6 R & CGTCCATCTITGCTTGGGAAATC \\
\hline p53 S & TTGGATCCATGTITTGCCAACTGGCC \\
\hline p53 AS & TTGAATTCAGGCTCCCCTTTCTTGCG \\
\hline PTEN F & GGACGAACTGGTGTAATGATATG \\
\hline PTEN R & TCTACTGTTITTGTGAAGTACAGC \\
\hline SDF-1S & GGGGGAATTCCATGAACGCCAAGGTCGTGGTC \\
\hline SDF-1 AS & GGGGTCTAGAGGGCATGGATGAATATAAGCTGC \\
\hline Sox2 S & ACCGGCGGCAACCAGAAGAACAG \\
\hline Sox2 AS & GCGCCGCGGCCGGTATTTAT \\
\hline TIMP1 F & ACT GGA AGC CCT TाT CAG AGC \\
\hline TIMP1 R & AAT TCC GAC CTC GTC ATC AGG \\
\hline VEGF AS & CGATCGTTCTGTATCAGTCTTTCC \\
\hline VEGF S & GAAGTGGTGAAGTTCATGGATGTC \\
\hline
\end{tabular}

Note: $F$, forward; $R$, reverse; $S$ : sense; $A S$, anti-sense. All the primers were described previously [104]. 
of an amplification cycle of $94^{\circ} \mathrm{C}$ for $30 \mathrm{~s}, 57^{\circ} \mathrm{C}$ for $30 \mathrm{~s}$, and $70^{\circ} \mathrm{C}$ for $30 \mathrm{~s}$ were used in PCR reactions in a 2720 Thermal Cycler from Applied Biosystems (Foster City, California, USA). All the primers used are shown in Table 2 and are as described previously [104].

\section{Immunocytochemistry}

The immunocytochemistry used has also been previously described [105]. Cells were grown on Matrigel-coated chamber slides and selective antibodies were applied after fixation and permeabilization. Images were taken on a Zeiss LSM 510 Meta Microscopy System using 40x or 63x objectives or an Olympus IX-70 fluorescence microscope using 4x, 10x, 20x, 40x, or 100x objectives.

\section{Western blot analysis}

The Western blot analysis used has also been previously described by us $[83,106,107]$. Briefly, cells cultured in one $10-\mathrm{cm}$ dish were washed three times with PBS, collected, and incubated in $500 \mu \mathrm{l}$ of lysis buffer $(10 \mathrm{mM}$ Tris, $\mathrm{pH} 7.5,50 \mathrm{mM} \mathrm{NaCl}, 1$ Triton X-100) for $30 \mathrm{~min}$ at $4^{\circ} \mathrm{C}$. Lysates were clarified by centrifugation at $15,000 \mathrm{xg}$ for $15 \mathrm{~min}$. After preclearing, supernatants were quantified with a protein assay. Fifty micrograms of the lysate protein were mixed with SDS-PAGE loading buffers and loaded into a lane, which was subjected to resolution by SDS-PAGE. The sample was subjected to immunoblot analysis with Caveolin-1 mouse monoclonal antibody (4 H312, sc-70516; Santa Cruz Biotech). Equivalent amounts of total cell lysates were loaded into all the lanes.

\section{Stereotactic surgical procedure with NOD/SCID mice}

All animal protocols were approved by our IACUC. Immune-deficient mice (NOD/SCID, 6-8 weeks old) were used. Animals were anesthetized with an intraperitoneal injection of a Ketamine/Xylazine cocktail (132 $\mathrm{mg} / \mathrm{kg}$ Ketamine $+8.8 \mathrm{mg} / \mathrm{kg}$ Xylazine), were immobilized in a stereotactic apparatus and received stereo tactically-guided injections of CD133+ cells into the right frontal lobe $(\sim 2 \mathrm{~mm}$ lateral and $1 \mathrm{~mm}$ anterior to bregma, at a $2.5 \mathrm{~mm}$ depth from the dural surface). The glioma cell line U87 (from ATCC, Manassas, VA) was used as a control. Injections were performed through a burr hole drilled into the skull after a skin incision. $6 \times 10^{3}-6 \times 10^{4}$ of cells in $2 \mathrm{ul}$ of PBS were injected with a 30 gauge 5 ul Hamilton syringe over a $3-5$ minute period. After retracting the needle over a $2-4$ minute period, bone-wax was used to occlude the burr hole, betadine applied to surgical area, and the skin was closed with skin glue or sutures. Post-surgical mice were kept on a heating pad to recover and eye ointment was applied.

\section{Histological analysis of mouse brain}

Prefixation was performed by transcardiac perfusion with lactated Ringer's solution followed by 4 bufferedparaformaldehyde. The brains were postfixed and embedded with paraffin and cut with a microtome. Brain sections were mounted on slides and stained with Harris' hematoxylin then counterstained with alcoholic eosin.

\section{Abbreviations \\ CT: Computed tomography; CSCs: Cancer stem cells; GBM: Glioblastoma multiforme; MRI: Magnetic resonance imaging; NSCs: Neural stem cells.}

\section{Competing interests}

The authors declare that they have no competing interests.

\section{Authors' contributions}

SCL conceived of the study, designed with coordination, carried out tumor processing and CSC isolation and in vitro and ex vivo culture, and drafted the manuscript. LTV carried out the PCR and Western blotting studies. HWH and WGL performed the surgery and analyzed MRI images. VK carried out the immunocytochemistry with technical help from AS. ZM performed all pathological analyses. QL, JW, and HZ carried out in vivo studies. HZY and JHW helped perform ex vivo studies. PHS participated in neural stem cell culture and advised on editing of the manuscript. WGL advised on conceiving of the study, participated in its design and coordination, and helped draft the manuscript. All authors read, revised, and approved the final manuscript.

\section{Acknowledgements}

Support came from the CHOC Children's Research Institute, CHOC Children's Foundation, CHOC Neuroscience Institute, the Austin Ford Tribute Fund and the WM Keck Foundation (to SCL), NIH NS052388 (to QL), NIH NS30884 and AG00836 (to JHW). Myrlee Cuiching, Heather J. Bierman, and Erin Sullivan are acknowledged for their assistance. Many thanks to Jeff Buzby, PhD, Shirley Williams, PhD, David Brick, PhD, Mei Chang, PhD, LeiQian Tai, PharmD, Diane Nugent, MD, Michael Ho, Tiffany Dao, Lisa Tachiki, Shi (Sherrie) Yu, Chung Ho Sun, PhD, Henry Hirschberg, MD-PhD, for their technical help. We thank Brent Dethlefs, Maria Minon, MD, Mustafa H Kabeer, MD, and Leonard S. Sender, MD, for their enthusiasm and support.

\section{Author details}

${ }^{1}$ Neuro-Oncology Research Laboratory, Center for Neuroscience and Stem Cell Research, Children's Hospital of Orange County (CHOC) Research Institute, 455 South Main Street, Orange, CA 92868, USA. ²Department of Neurological Surgery, Saint Joseph Hospital, Orange, CA 92868, USA. ${ }^{3}$ Department of Neurological Surgery, University of California Irvine, Orange, CA 92862, USA. ${ }^{4}$ Department of Neurology, University of California Irvine, Orange, CA 92862, USA. ${ }^{5}$ Department of Biological Science, California State University, Fullerton, CA 92834, USA. ${ }^{6}$ Department of Pathology and Laboratory Medicine, Good Samaritan Hospital Medical Center, 1000 Montauk Highway, West Islip, NY 11795, USA. ${ }^{7}$ Department of Neurosciences, Beckman Research Institute of the City of Hope, Duarte, CA 91010, USA. ${ }^{8}$ National Human Neural Stem Cell Resource, Center for Neuroscience and Stem Cell Research, CHOC Children's Hospital Research Institute, 455 South Main Street, Orange, CA 92868, USA. 'Developmental Biology Center, University of California Irvine, Irvine, CA 92612, USA.

Received: 13 July 2012 Accepted: 10 August 2012 Published: 20 September 2012

\section{References}

1. Louis DN: Molecular pathology of malignant gliomas. Annu Rev Pathol 2006, 1:97-117.

2. Li SC, Loudon WG: A novel and generalizable organotypic slice platform to evaluate stem cell potential for targeting pediatric brain tumors. Cancer Cell International 2008, 8(9):1-11. 
3. Meeske KA, Patel SK, Palmer SN, Nelson MB, Parow AM: Factors associated with health-related quality of life in pediatric cancer survivors. Pediatr Blood Cancer 2007, 49(3):298-305

4. Zebrack BJ, Gurney JG, Oeffinger K, Whitton J, Packer RJ, Mertens A, Turk N Castleberry R, Dreyer Z, Robison LL, et al: Psychological outcomes in longterm survivors of childhood brain cancer: a report from the childhood cancer survivor study. J Clin Oncol 2004, 22(6):999-1006.

5. Singh S, Dirks PB: Brain tumor stem cells: identification and concepts. Neurosurg Clin N Am 2007, 18(1):31-38. viii.

6. Reya T, Morrison SJ, Clarke MF, Weissman IL: Stem cells, cancer, and cancer stem cells. Nature 2001, 414(6859):105-111.

7. Dirks PB: Brain tumour stem cells: the undercurrents of human brain cancer and their relationship to neural stem cells. Philos Trans $R$ Soc Lond B Biol Sci 2008, 363(1489):139-152.

8. Tan BT, Park CY, Ailles LE, Weissman IL: The cancer stem cell hypothesis: a work in progress. Lab Invest 2006, 86(12):1203-1207.

9. Quintana E, Shackleton M, Sabel MS, Fullen DR, Johnson TM, Morrison S.: Efficient tumour formation by single human melanoma cells. Nature 2008, 456(7222):593-598

10. Kennedy JA, Barabe F, Poeppl AG, Wang JC, Dick JE: Comment on "Tumor growth need not be driven by rare cancer stem cells". Science 2007, 318 (5857):1722. author reply 1722.

11. Adams JM, Kelly PN, Dakic A, Carotta S, Nutt SL, Strasser A: Role of "cancer stem cells" and cell survival in tumor development and maintenance. Cold Spring Harb Symp Quant Biol 2008, 73:451-459.

12. Kelly PN, Dakic A, Adams JM, Nutt SL, Strasser A: Tumor growth need not be driven by rare cancer stem cells. Science 2007, 317(5836):337.

13. Li SC, Loudon WG: Stem Cell Therapy for Paediatric Malignant Brain Tumours: The Silver Bullet? ONcology News (UK), June-July 2008, ISSN 17514975 2008, 3(1):10-14. http://www.oncologynews.biz/pdf/jun_jul_08/ ONJJ08_stemcell.pdf (Accessed May 14, 2008)

14. Aboody KS, Brown A, Rainov NG, Bower KA, Liu S, Yang W, Small JE, Herrlinger U, Ourednik V, Black PM, et al: Neural stem cells display extensive tropism for pathology in adult brain: evidence from intracranial gliomas. ProcNat/AcadSciUSA 2000, 97(23):12846-12851.

15. Aboody KS, Najbauer J, Danks MK: Stem and progenitor cell-mediated tumor selective gene therapy. Gene Ther 2008, 15(10):739-752.

16. Abel TW, Clark C, Bierie B, Chytil A, Aakre M, Gorska A, Moses HL: GFAP-Cremediated activation of oncogenic K-ras results in expansion of the subventricular zone and infiltrating glioma. Mol Cancer Res 2009, 7(5):645-653.

17. Duntsch C, Zhou Q, Weimar JD, Frankel B, Robertson JH, Pourmotabbed T: Up-regulation of neuropoiesis generating glial progenitors that infiltrate rat intracranial glioma. J Neurooncol 2005, 71(3):245-255.

18. Fujita M, Sato M, Nakamura M, Kudo K, Nagasaka T, Mizuno M, Amano E, Okamoto $Y$, Hotta $Y$, Hatano $\mathrm{H}$, et al: Multicentric atypical teratoid/ rhabdoid tumors occurring in the eye and fourth ventricle of an infant: case report. J Neurosurg 2005, 102(3 Suppl):299-302.

19. Morota N, Deletis V, Epstein FJ, Kofler M, Abbott R, Lee M, Ruskin K: Brain stem mapping: neurophysiological localization of motor nuclei on the floor of the fourth ventricle. Neurosurgery 1995, 37(5):922-929. discussion 929-930.

20. Phi JH, Park SH, Chae JH, Hong KH, Park SS, Kang JH, Jun JK, Cho BK, Wang KC, Kim SK: Congenital subependymal giant cell astrocytoma: clinical considerations and expression of radial glial cell markers in giant cells. Childs Nerv Syst 2008, 24(12):1499-1503.

21. Stecca B, Ruiz i Altaba A: Brain as a paradigm of organ growth: Hedgehog-Gli signaling in neural stem cells and brain tumors. J Neurobiol 2005, 64(4):476-490.

22. Uchida K, Mukai M, Okano H, Kawase T: Possible oncogenicity of subventricular zone neural stem cells: case report. Neurosurgery 2004, 55(4):977-978

23. Yano H, Ohe N, Shinoda J, Yoshimura S, Iwama T: Immunohistochemical study concerning the origin of neurocytoma-a case report. Pathol Oncol Res 2009, 15(2):301-305.

24. Li SC, Jin Y, Loudon WG, Song Y, Ma Z, Weiner LP, Zhong JF: From the Cover: Increase developmental plasticity of human keratinocytes with gene suppression. Proc Natl Acad Sci U S A 2011, 108(31):12793-12798.

25. Li SC, Lee KL, Luo J, Zhong JF, Loudon WG: Convergence of normal stem cell and cancer stem cell developmental stage: Implication for differential therapies. World J Stem Cells 2011, 3(9):83-88.
26. Li SC, Lee $\mathrm{KL}$, Luo J: Control dominating subclones for managing cancer progression and posttreatment recurrence by subclonal switchboard signal: implication for new therapies. Stem Cells Dev 2012, 21(4):503-506

27. Flanagan LA, Rebaza LM, Derzic S, Schwartz PH, Monuki ES: Regulation of human neural precursor cells by laminin and integrins. J Neurosci Res 2006, 83(5):845-856.

28. Engler AJ, Sen S, Sweeney HL, Discher DE: Matrix elasticity directs stem cell lineage specification. Cell 2006, 126(4):677-689.

29. Schwartz PH, Bryant PJ, Fuja TJ, Su H, O'Dowd DK, Klassen H: Isolation and characterization of neural progenitor cells from post-mortem human cortex. J Neurosci Res 2003, 74(6):838-851.

30. Li S, Seitz R, Lisanti MP: Phosphorylation of caveolin by Src tyrosine kinases: The à-isoform of caveolin is selectively phosphorylated by v-Src in vivo. J Biol Chem 1996, 271:3863-3868.

31. Dirks PB, Fogarty MP, Emmenegger BA, Grasfeder LL, Oliver TG, Wechsler-Reya RJ: Brain tumour stem cells: the undercurrents of human brain cancer and their relationship to neural stem cells. Fibroblast growth factor blocks Sonic hedgehog signaling in neuronal precursors and tumor cells. Philos Trans R Soc Lond B Biol Sci 2007, 19(8):19.

32. Sanai N, Varez-Buylla A, Berger MS: Neural stem cells and the origin of gliomas. N Engl J Med 2005, 353(8):811-822.

33. Singh SK, Clarke ID, Hide T, Dirks PB: Cancer stem cells in nervous system tumors. Oncogene 2004, 23(43):7267-7273.

34. Hemmati HD, Nakano I, Lazareff JA, Masterman-Smith M, Geschwind DH, Bronner-Fraser M, Kornblum HI: Cancerous stem cells can arise from pediatric brain tumors. Proc Natl Acad Sci USA 2003, 100(25):15178-15183.

35. Yuan X, Curtin J, Xiong Y, Liu G, Waschsmann-Hogiu S, Farkas DL, Black KL, Yu JS: Isolation of cancer stem cells from adult glioblastoma multiforme. Oncogene 2004, 23(58):9392-9400.

36. Dirks PB: Cancer: stem cells and brain tumours. Nature 2006, 444 (7120):687-688.

37. Tunici $P$, Irvin D, Liu G, Yuan $X$, Zhaohui $Z, N$ g H, Yu JS: Brain tumor stem cells: new targets for clinical treatments? Neurosurg Focus 2006, 20(4):E27.

38. Xu Q, Liu G, Yuan X, Xu M, Wang H, Ji J, Konda B, Black KL, Yu JS: Antigenspecific T-cell response from dendritic cell vaccination using cancer stem-like cell-associated antigens. Stem Cells 2009, 27(8):1734-1740.

39. Yu JJ, Sun X, Yuan X, Lee JW, Snyder EY, Yu JS: Immunomodulatory neural stem cells for brain tumour therapy. Expert Opin Biol Ther 2006, 6 (12):1255-1262.

40. Murat A, Migliavacca E, Gorlia T, Lambiv WL, Shay T, Hamou MF, de Tribolet N, Regli L, Wick W, Kouwenhoven MC, et al: Stem cell-related "self-renewal" signature and high epidermal growth factor receptor expression associated with resistance to concomitant chemoradiotherapy in glioblastoma. J Clin Oncol 2008, 26(18):3015-3024

41. Strojnik T, Rosland GV, Sakariassen PO, Kavalar R, Lah T: Neural stem cell markers, nestin and musashi proteins, in the progression of human glioma: correlation of nestin with prognosis of patient survival. Surg Neurol 2007, 68(2):133-143. discussion 143-134.

42. Kavsan V, Shostak K, Dmitrenko V, Zozulya Y, Rozumenko V, DemotesMainard J: Characterization of genes with increased expression in human glioblastomas. Tsitol Genet 2005, 39(6):37-49.

43. Heimberger AB, McGary EC, Suki D, Ruiz M, Wang H, Fuller GN, Bar-Eli M: Loss of the AP-2alpha transcription factor is associated with the grade of human gliomas. Clin Cancer Res 2005, 11(1):267-272.

44. Grzybicki DM, Moore SA: Implications of prognostic markers in brain tumors. Clin Lab Med 1999, 19(4):833-847.

45. Jennings MT, Kaariainen IT, Gold L, Maciunas RJ, Commers PA: TGF beta 1 and TGF beta 2 are potential growth regulators for medulloblastomas, primitive neuroectodermal tumors, and ependymomas: evidence in support of an autocrine hypothesis. Hum Pathol 1994, 25(5):464-475.

46. Mastronardi L, Guiducci A, Puzzilli F, Ruggeri A: Relationship between Ki-67 labeling index and survival in high-grade glioma patients treated after surgery with tamoxifen. J Neurosurg Sci 1999, 43(4):263-270.

47. Sampath P, Weaver CE, Sungarian A, Cortez S, Alderson L, Stopa EG: Cerebrospinal fluid (vascular endothelial growth factor) and serologic (recoverin) tumor markers for malignant glioma. Cancer Control 2004, 11(3):174-180

48. Schiebe M, Ohneseit P, Hoffmann W, Meyermann R, Rodemann HP, Bamberg M: Analysis of $\mathrm{mdm} 2$ and p53 gene alterations in glioblastomas and its correlation with clinical factors. J Neurooncol 2000, 49(3):197-203. 
49. Tada K, Shiraishi S, Kamiryo T, Nakamura H, Hirano H, Kuratsu J, Kochi M, Saya H, Ushio Y: Analysis of loss of heterozygosity on chromosome 10 in patients with malignant astrocytic tumors: correlation with patient age and survival. J Neurosurg 2001, 95(4):651-659.

50. Xin W, Paulino AF: Prognostic factors in malignant mixed tumors of the salivary gland: correlation of immunohistochemical markers with histologic classification. Ann Diagn Pathol 2002, 6(4):205-210.

51. Das S, Srikanth M, Kessler JA: Cancer stem cells and glioma. Nat Clin Pract Neurol 2008, 4(8):427-435.

52. Bonavia R, Inda MM, Cavenee WK, Furnari FB: Heterogeneity maintenance in glioblastoma: a social network. Cancer Res 2011, 71(12):4055-4060

53. Qiang L, Yang Y, Ma YJ, Chen FH, Zhang LB, Liu W, Qi Q, Lu N, Tao L, Wang $X T$, et al: Isolation and characterization of cancer stem like cells in human glioblastoma cell lines. Cancer Lett 2009, 279(1):13-21.

54. Huttner HB, Janich P, Kohrmann M, Jaszai J, Siebzehnrubl F, Blumcke I, Suttorp M, Gahr M, Kuhnt D, Nimsky C, et al: The stem cell marker prominin-1/CD133 on membrane particles in human cerebrospinal fluid offers novel approaches for studying central nervous system disease. Stem Cells 2008, 26(3):698-705.

55. Cheng JX, Liu BL, Zhang X: How powerful is CD133 as a cancer stem cell marker in brain tumors? Cancer Treat Rev 2009,

56. Zeppernick F, Ahmadi R, Campos B, Dictus C, Helmke BM, Becker N, Lichter P, Unterberg A, Radlwimmer B, Herold-Mende CC: Stem cell marker CD133 affects clinical outcome in glioma patients. Clin Cancer Res 2008, 14 (1):123-129

57. Singh SK, Clarke ID, Terasaki M, Bonn VE, Hawkins C, Squire J, Dirks PB: Identification of a cancer stem cell in human brain tumors. Cancer Res 2003, 63(18):5821-5828.

58. Singh SK, Hawkins C, Clarke ID, Squire JA, Bayani J, Hide T, Henkelman RM, Cusimano MD, Dirks PB: Identification of human brain tumour initiating cells. Nature 2004, 432(7015):396-401.

59. Pfenninger CV, Roschupkina T, Hertwig F, Kottwitz D, Englund E, Bengzon J, Jacobsen SE, Nuber UA: CD133 is not present on neurogenic astrocytes in the adult subventricular zone, but on embryonic neural stem cells, ependymal cells, and glioblastoma cells. Cancer Res 2007, 67(12):5727-5736.

60. Galli R, Binda E, Orfanelli U, Cipelletti B, Gritti A, De Vitis S, Fiocco R, Foroni C, Dimeco F, Vescovi A: Isolation and characterization of tumorigenic, stem-like neural precursors from human glioblastoma. Cancer Res 2004, 64(19):7011-7021.

61. Lathia JD, Gallagher J, Myers JT, Li M, Vasanji A, McLendon RE, Hjelmeland $A B$, Huang $A Y$, Rich JN: Direct in vivo evidence for tumor propagation by glioblastoma cancer stem cells. PLoS One 2011, 6(9):e24807.

62. Shu Q, Wong KK, Su JM, Adesina AM, Yu LT, Tsang YT, Antalffy BC, Baxter P, Perlaky L, Yang J, et al: Direct orthotopic transplantation of fresh surgical specimen preserves CD133+ tumor cells in clinically relevant mouse models of medulloblastoma and glioma. Stem Cells 2008, 26(6):1414-1424.

63. Gong X, Schwartz PH, Linskey ME, Bota DA: Neural stem/progenitors and glioma stem-like cells have differential sensitivity to chemotherapy. Neurology 2011, 76(13):1126-1134.

64. Kamoun WS, Ley CD, Farrar CT, Duyverman AM, Lahdenranta J, Lacorre DA, Batchelor TT, di Tomaso E, Duda DG, Munn LL, et al: Edema control by cediranib, a vascular endothelial growth factor receptor-targeted kinase inhibitor, prolongs survival despite persistent brain tumor growth in mice. J Clin Oncol 2009, 27(15):2542-2552.

65. Zajc I, Hreljac I, Lah T: Cathepsin L affects apoptosis of glioblastoma cells: a potential implication in the design of cancer therapeutics. Anticancer Res 2006, 26(5A):3357-3364.

66. Steinert PM, Liem RKH: Intermediate filament dynamics. Cell (Cambridge) 1990, 60(4):521-523.

67. Shih $\mathrm{AH}, \mathrm{Holland} \mathrm{EC}$ : Notch signaling enhances nestin expression in gliomas. Neoplasia 2006, 8(12):1072-1082.

68. Strojnik T, Røsland GV, Sakariassen PO, Kavalar R, Lah T: Neural stem cell markers, nestin and musashi proteins, in the progression of human glioma: correlation of nestin with prognosis of patient survival. Surg Neurol 2007, 68(2):133-143.

69. Rooprai HK, McCormick D: Proteases and their inhibitors in human brain tumours: a review. Anticancer Res 1997, 17(6B):4151-4162.

70. Levicar N, Nuttall RK, Lah TT: Proteases in brain tumour progression. Acta Neurochir (Wien) 2003, 145(9):825-838.
71. Ezhilarasan R, Mohanam I, Govindarajan K, Mohanam S: Glioma cells suppress hypoxia-induced endothelial cell apoptosis and promote the angiogenic process. Int J Oncol 2007, 30(3):701-707.

72. Guo P, Imanishi Y, Cackowski FC, Jarzynka MJ, Tao HQ, Nishikawa R, Hirose T, Hu B, Cheng SY: Up-regulation of angiopoietin-2, matrix metalloprotease-2, membrane type 1 metalloprotease, and laminin 5 gamma 2 correlates with the invasiveness of human glioma. Am J Pathol 2005, 166(3):877-890.

73. Hu B, Guo P, Fang Q, Tao HQ, Wang D, Nagane M, Huang HJ, Gunji Y, Nishikawa R, Alitalo K, et al: Angiopoietin-2 induces human glioma invasion through the activation of matrix metalloprotease-2. Proc Natl Acad Sci U S A 2003, 100(15):8904-8909.

74. Hu B, Jarzynka MJ, Guo P, Imanishi Y, Schlaepfer DD, Cheng SY: Angiopoietin 2 induces glioma cell invasion by stimulating matrix metalloprotease 2 expression through the alphavbeta 1 integrin and focal adhesion kinase signaling pathway. Cancer Res 2006, 66(2):775-783.

75. Wong ET, Alsop D, Lee D, Tam A, Barron L, Bloom J, Gautam S, Wu JK: Cerebrospinal fluid matrix metalloproteinase- 9 increases during treatment of recurrent malignant gliomas. Cerebrospinal Fluid Res 2008, $5: 1$

76. Sivaparvathi M, Yamamoto M, Nicolson GL, Gokaslan ZL, Fuller GN, Liotta LA, Sawaya R, Rao JS: Expression and immunohistochemical localization of cathepsin $\mathrm{L}$ during the progression of human gliomas. Clin Exp Metastasis 1996, 14(1):27-34.

77. Levicar N, Dewey RA, Daley E, Bates TE, Davies D, Kos J, Pilkington GJ, Lah $\Pi$ : Selective suppression of cathepsin $L$ by antisense cDNA impairs human brain tumor cell invasion in vitro and promotes apoptosis. Cancer Gene Ther 2003, 10(2):141-151.

78. Strojnik T, Zidanik B, Kos J, Lah T: Cathepsins B and L are markers for clinically invasive types of meningiomas. Neurosurgery 2001, 48(3):598-605.

79. van Lohuizen M, Verbeek S, Scheijen B, Wientjens E, van der Gulden H, Berns A: Identification of cooperating oncogenes in $E$ mu-myc transgenic mice by provirus tagging. Cell 1991, 65(5):737-752.

80. Haupt Y, Bath ML, Harris AW, Adams JM: bmi-1 transgene induces lymphomas and collaborates with myc in tumorigenesis. Oncogene 1993, 8(11):3161-3164

81. Godlewski J, Nowicki MO, Bronisz A, Williams S, Otsuki A, Nuovo G, Raychaudhury A, Newton HB, Chiocca EA, Lawler S: Targeting of the Bmi-1 oncogene/stem cell renewal factor by microRNA-128 inhibits glioma proliferation and self-renewal. Cancer Res 2008, 68(22):9125-9130.

82. Martin S, Cosset EC, Terrand J, Maglott A, Takeda K, Dontenwill M: Caveolin1 regulates glioblastoma aggressiveness through the control of alpha(5) beta(1) integrin expression and modulates glioblastoma responsiveness to SJ749, an alpha(5)beta(1) integrin antagonist. Biochim Biophys Acta 2009, 1793(2):354-367.

83. Li S, Okamoto T, Chun M, Sargiacomo M, Casanova JE, Hansen SH, Nishimoto I, Lisanti MP: Evidence for a regulated interaction of heterotrimeric G proteins with caveolin. J Biol Chem 1995, 270(26):15693-15701.

84. Li S, Song KS, Lisanti MP: Expression and characterization of recombinant caveolin: Purification by poly-histidine tagging and cholesteroldependent incorporation into defined lipid membranes. JBio/Chem 1996, 271:568-573.

85. Lisanti MP, Scherer P, Tang ZL, Sargiacomo M: Caveolae, caveolin and caveolin-rich membrane domains: A signalling hypothesis. Trends Cell Biol 1994, 4:231-235.

86. Tahir SA, Ren C, Timme TL, Gdor Y, Hoogeveen R, Morrisett JD, Frolov A, Ayala G, Wheeler TM, Thompson TC: Development of an Immunoassay for Serum Caveolin-1 A Novel Biomarker for Prostate Cancer 1, Volume 9: AACR; 2003:3653-3659.

87. Tahir SA, Frolov A, Hayes TG, Mims MP, Miles BJ, Lerner SP, Wheeler TM, Ayala G, Thompson TC, Kadmon D: Preoperative serum caveolin-1 as a prognostic marker for recurrence in a radical prostatectomy cohort. Clin Cancer Res 2006, 12(16):4872-4875.

88. Witkiewicz AK, Dasgupta A, Sotgia F, Mercier I, Pestell RG, Sabel M, Kleer CG, Brody JR, Lisanti MP: An Absence of Stromal Caveolin-1 Expression Predicts Early Tumor Recurrence and Poor Clinical Outcome in Human Breast Cancers. Am J Pathol 2009.

89. Piccirillo SG, Combi R, Cajola L, Patrizi A, Redaelli S, Bentivegna A, Baronchelli S, Maira G, Pollo B, Mangiola A, et al: Distinct pools of cancer stem-like cells coexist within human glioblastomas and display different 
tumorigenicity and independent genomic evolution. Oncogene 2009, 28(15):1807-1811.

90. Li SC, Han YP, Dethlefs BA, Loudon WG: Therapeutic Window, a Critical Developmental Stage for Stem Cell Therapies. Curr Stem Cell Res Ther 2010.

91. Verhaak RG, Hoadley KA, Purdom E, Wang V, Qi Y, Wilkerson MD, Miller CR, Ding L, Golub T, Mesirov JP, et al: Integrated genomic analysis identifies clinically relevant subtypes of glioblastoma characterized by abnormalities in PDGFRA, IDH1, EGFR, and NF1. Cancer Cell 2010, 17(1):98-110.

92. Turcan S, Rohle D, Goenka A, Walsh LA, Fang F, Yilmaz E, Campos C, Fabius AW, Lu C, Ward PS, et al: IDH1 mutation is sufficient to establish the glioma hypermethylator phenotype. Nature 2012, 483(7390):479-483.

93. Feng J, Kim ST, Liu W, Kim JW, Zhang Z, Zhu Y, Berens M, Sun J, Xu J: An integrated analysis of germline and somatic, genetic and epigenetic alterations at 9p21.3 in glioblastoma. Cancer 2012, 118(1):232-240

94. Pollard SM, Yoshikawa K, Clarke ID, Danovi D, Stricker S, Russell R, Bayani J, Head R, Lee M, Bernstein M, et al: Glioma stem cell lines expanded in adherent culture have tumor-specific phenotypes and are suitable for chemical and genetic screens. Cell Stem Cell 2009, 4(6):568-580.

95. Loring JF, Wesselschmidt RL, Schwartz PH: Human Stem Cell Manual: A Laboratory Guide, Academic Press; 2007.

96. Nethercott H, Maxwell H, Schwartz PH: Neural progenitor cell culture. In Human stem cell manual: A laboratory guide. Edited by Loring JF, Wesselschmidt RL, Schwartz PH. Boston, London, New York: Academic Press, Elsevier; 2007:309-331.

97. Galli R, Binda E, Orfanelli U, Cipelletti B, Gritti A, De VS, Fiocco R, Foroni C, Dimeco F, Vescovi A: Isolation and characterization of tumorigenic, stemlike neural precursors from human glioblastoma. Cancer Res 2004, 64 (19):7011-7021.

98. Grimm EA, Loudon WG: The generation and quantitation of cell-mediated cytotoxicity. In Cytokines: A practical approach. 2nd edition. Edited by Balkwill FR. Oxford: IRL Press; 1995:197-214.

99. Berglund DL, Taffs RE, Robertson NP: A rapid analytical technique for flow cytometric analysis of cell viability using calcofluor white M2R. Cytometry 1987, 8(4):421-426

100. Diaz TM, Pertega S, Ortega D, Lopez E, Centeno A, Manez R, Domenech N: FDA/PI flow cytometry assay of complement-mediated cytotoxicity of antibodies generated during xenotransplantation. Cytometry A 2004, 62(1):54-60.

101. Saha NR, Usami T, Suzuki Y: A double staining flow cytometric assay for the detection of steroid induced apoptotic leucocytes in common carp (Cyprinus carpio). Dev Comp Immunol 2003, 27(5):351-363.

102. Koleske AJ, Baltimore D, Lisanti MP: Reduction of caveolin and caveolae in oncogenically transformed cells. Proc Natl Acad Sci USA 1995, 92(1381-1385).

103. Yin HZ, Sensi SL, Carriedo SG, Weiss JH: Dendritic localization of $\mathrm{Ca}(2+)$-permeable AMPA/kainate channels in hippocampal pyramidal neurons. J Comp Neurol 1999, 409(2):250-260.

104. Li S, Kirov I, Klassen HK, Schwartz PH: Characterization of stem cells using reverse transcriptase polymerase chain reaction. In Human stem cell manual: a laboratory guide. Edited by Loring JF, Wesselschmidt RL, Schwartz PH. Boston, New York, London: Academic Press, Elsevier; 2007:127-148

105. Flanagan LA, Ziaeian B, Palmer T, Schwartz PH: Immunocytochemical analysis of stem cells. In Human Stem Cell Manual: A Laboratory Guide. Edited by Loring JF, Wesselschmidt RL, Schwartz PH. Boston, New York: Academic Press, Elsevier; 2007:108-126.

106. Ju X, Katiyar S, Wang C, Liu M, Jiao X, Li S, Zhou J, Turner J, Lisanti MP, Russell RG, et al: Akt1 governs breast cancer progression in vivo. Proc Natl Acad Sci U S A 2007, 104(18):7438-7443.

107. Li S, Couet J, Lisanti MP: Src tyrosine kinases, Galpha subunits, and H-Ras share a common membrane-anchored scaffolding protein, caveolin. Caveolin binding negatively regulates the auto-activation of Src tyrosine kinases. J Biol Chem 1996, 271(46):29182-29190.

doi:10.1186/1475-2867-12-41

Cite this article as: Li et al:: Cancer stem cells from a rare form of glioblastoma multiforme involving the neurogenic ventricular wall. Cancer Cell International 2012 12:41.

\section{Submit your next manuscript to BioMed Central and take full advantage of:}

- Convenient online submission

- Thorough peer review

- No space constraints or color figure charges

- Immediate publication on acceptance

- Inclusion in PubMed, CAS, Scopus and Google Scholar

- Research which is freely available for redistribution 